\title{
Monitoring of UN sustainable development goal SDG-9.1.1: study of Algerian "Belt and Road" expressways constructed by China
}

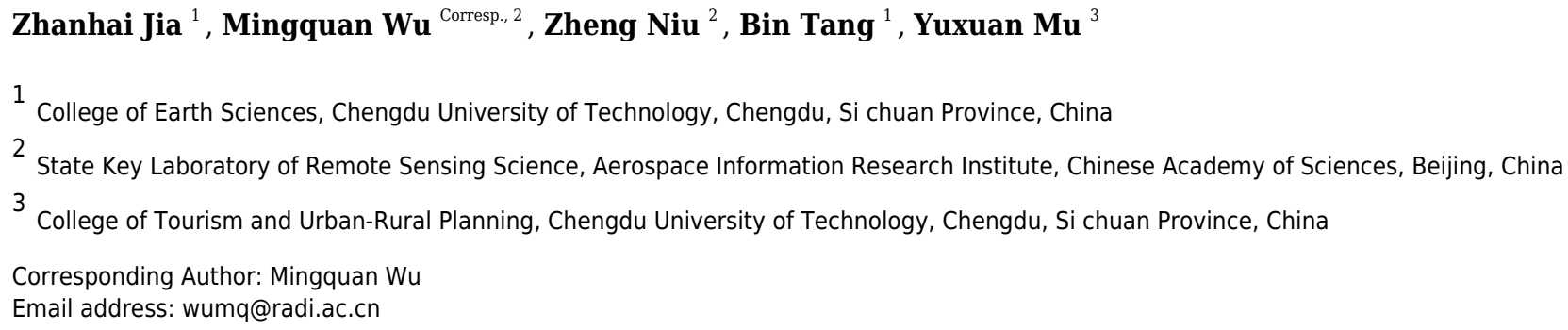

The proportion of the rural population who live within $2 \mathrm{~km}$ of an all-season road is an indicator of the United Nations' Sustainable Development Goals (SDGs) 9.1.1. This paper aims to calculate SDG indicator 9.1.1 in the proximity of five Algerian expressways. Three monitoring methods are proposed for different spatial regions based on the five expressways built by China's Belt and Road Initiative Project. These methods are based on remote sensing and WorldPop and The High Resolution Settlement Layer (HRSL) population data. The results indicate that (1) the WorldPop population statistics show that the five expressways built by China's Belt Project have increased the rural population of the $2 \mathrm{~km}$ buffer zone by 196,000 between the start of construction and eight years after its completion. By the end of 2019 , the population increased by 252,687 , accounting for $9.16 \%$ of the rural population. (2) Based on populations estimated form built-up index (NDBI) building areas, the rural populations within the $2 \mathrm{~km}$ buffer area of the Bejaia-Haniff Expressway in 2011, 2015, and 2019 were 273,118, 306,430, and 375,408, respectively. (3) HRSL population grid statistics indicate that, in 2015, the populations were: East-West Expressway $=911,549$, Bejaia Expressway $=127,471$, Tipaza Expressway $=71,411$, North-South Expressway $=30,583$, and Cherchell Ring Expressway $=41,657$. (4) A visual interpretation method based on Google Earth imagery was used to count the number of buildings and number of building floors in the town of Tikhramtath. Based on the estimated population of each building and floor, the population of Tikhramtath town in 2011, 2015, 2017, and 2019 was estimated as 1790, 2785, 3365, and 3970, respectively. (5) Through analysis and accuracy assessment, the appropriate statistical methods for different regions were determined. 


\section{Monitoring of UN Sustainable Development Goal SDG- 2 9.1.1: Study of Algerian "Belt and Road" Expressways 3 Constructed by China}

4 Zhanhai $\mathrm{Jia}^{1}$, Mingquan $\mathrm{Wu}^{2}$, Zheng $\mathrm{Niu}^{2}$, Bin Tang ${ }^{1}, \mathrm{Yuxuan} \mathrm{Mu}^{3}$

$5{ }^{1}$ College of Earth Sciences, Chengdu University of Technology, Chengdu, China;

$6 \quad{ }^{2}$ State Key Laboratory of Remote Sensing Science, Aerospace Information Research Institute, Chinese

7 Academy of Sciences, Beijing, China;

$8{ }^{3}$ College of Tourism and Urban-Rural Planning, Chengdu University of Technology, Chengdu, China;

10 Corresponding Author:

11 Mingquan $\mathrm{Wu}^{2}$

12 P.O.Box 9718, Datun Road, Chaoyang, Beijing, 100101, China;

14 Email address: wumq@radi.ac.cn;Tel.:+86-10-6480-6258 


\section{Abstract}

24

25

26

27

28

29

30

31

32

33

34

35

36

37

38

39

40

41

42

43

44

45

46

47

48

49

50

51

52

53

54

55

56

57

58

59

The proportion of the rural population who live within $2 \mathrm{~km}$ of an all-season road is an indicator of the United Nations' Sustainable Development Goals (SDGs) 9.1.1. This paper aims to calculate SDG indicator 9.1.1 in the proximity of five Algerian expressways. Three monitoring methods are proposed for different spatial regions based on the five expressways built by China's Belt and Road Initiative Project. These methods are based on remote sensing and WorldPop and The High Resolution Settlement Layer (HRSL) population data. The results indicate that (1) the WorldPop population statistics show that the five expressways built by China's Belt Project have increased the rural population of the $2 \mathrm{~km}$ buffer zone by 196,000 between the start of construction and eight years after its completion. By the end of 2019, the population increased by 252,687 , accounting for $9.16 \%$ of the rural population. (2) Based on populations estimated form built-up index (NDBI) building areas, the rural populations within the $2 \mathrm{~km}$ buffer area of the Bejaia-Haniff Expressway in 2011, 2015, and 2019 were 273,118, 306,430, and 375,408, respectively. (3) HRSL population grid statistics indicate that, in 2015, the populations were: East-West Expressway $=911,549$, Bejaia Expressway $=127,471$, Tipaza Expressway $=71,411$, North-South Expressway $=30,583$, and Cherchell Ring Expressway =41,657. (4) A visual interpretation method based on Google Earth imagery was used to count the number of buildings and number of building floors in the town of Tikhramtath. Based on the estimated population of each building and floor, the population of Tikhramtath town in 2011, 2015, 2017, and 2019 was estimated as 1790, 2785, 3365, and 3970, respectively. (5) Through analysis and accuracy assessment, the appropriate statistical methods for different regions were determined.

\section{Introduction}

The United Nations (UN) Sustainable Development Goals (SDGs) were formally adopted at the UN Sustainable Development Summit in 2015. The goals aim to take 15 years to solve social, economic and environmental development issues in three dimensions, and adopt a sustainable development path. The SDGs contain 17 universal goals and 169 target objectives (Chen et al., 2018). An SDG indicator framework was officially announced and implemented in 2017 by the UN General Assembly. Since nine of these indicators are duplicated and belong to two or more targets, the actual index contains 232 items (Chen et al., 2018). Indicator 9.1.1 calculates the proportion of the rural population living within $2 \mathrm{~km}$ of an all-season road (Commission UNS, 2014).

Well-connected road transportation is an important part of achieving inclusive and sustainable growth. It can ensure that various production activities are carried out in an orderly manner so that each production factor can achieve a reasonable allocation of time and space (Bhattacharyay, 2015). Rural roads are the basic component of expressway networks and have important strategic 
60 significance in promoting regional economic development, improving the living standards of 61 rural residents, and improving rural consumption. Indicator 9.1.1 focuses on assessing the level 62 of transportation infrastructure construction and its impacts on economic development and people's well-being (Xu, Bai \& Chen, 2019). In 2016, the Chinese government issued the China Implementation Plan for the 2030 Agenda for Sustainable Development, which details China's plans to implement 17 SDG universal goals and 169 target objectives within the next 15 years (Wei et al., 2018). However, at present, Chinese scholars have mainly conducted research and evaluation of domestic pilot areas, and research on foreign areas is lacking. China's Belt and Road infrastructure interoperability major projects are fast, which has strongly promoted local socioeconomic development and population growth (Li et al., 2019; Chen \& Li, 2018). The present study uses five expressways built in Algeria by China's Belt and Road Initiative Project as an example with which to calculate progress in indicator 9.1.1.

At present, researchers in China and elsewhere have used several methods to evaluate the SDG9.1.1 indicator. The World Bank Group defines the rural access index (RAI) as the proportion of the rural population who live within $2 \mathrm{~km}$ of an all-season road. This was defined together with an official method of measurement based on locally representative household surveys. Current estimates of the RAI indicate that some 900 million rural dwellers worldwide do not have adequate access to a formal transport system (Roberts, Kc \& Rastogi, 2006). Mikou et al. (2019) used WorldPop population and Open Street Map network data to estimate the RAI and found that, assuming optimistic GDP growth, rural accessibility would only increase from 39 to 52 percent by 2030 across all developing countries. For this indicator, Mariathasan, Bezuidenhoudt \& Olympio (2019) used Namibia as an example to calculate the possibility of road traffic through the global population grid. They compared four population datasets and the road networks of the OSM and NSA National Space Infrastructure (NSDI), and used the GEE APP tool to calculate the RAI. Xu, Bai and Chen (2019) added the three indicators road density, accessibility, and total postal service to build a new index. The revised RAI fully considers urban disadvantaged groups and eliminates the dependence of the original indicators on urbanrural boundary data. Qiu et al. (2019) used Deqing County in China as an example for evaluating the SDG-9.1.1 indicator. They used the building area and number of floors as weighting factors to establish a classification model. Population data with a spatial resolution of $30 \mathrm{~m}$ was obtained for sustainability analysis. SDG evaluations based on population data are more accurate and effective than those based on traditional methods. The Office for National Statistics (ONS) used the Ordnance Survey (OS) Master Map Integrated Transport Network (ITN) Layer as a basis for calculations, together with a population grid based on the 2011 Census, and the ONS' urban/rural classification to select rural areas. The data showed that more than $99 \%$ of people live within 2 $\mathrm{km}$ of an all-season road (Frensis, 2018). The above research found that WorldPop population data is updated slowly and has low spatial resolution (the raster cell size is $100 \mathrm{~m}$ ), making it impossible to count individual buildings. Most SDG-9.1.1 indicator evaluations are conducted at 
99 the national and provincial levels, and there is no precise way to evaluate small areas or newly

100 constructed single expressway projects.

101

102 In response to this problem, we selected high-resolution remote sensing images and different

103 population data. High-resolution remote sensing images have the advantages of high spatial

104 resolution that provides rich and clear spatial information on ground features. It can clearly

105 express spatial and surface texture structures and provide clear edge information and high

106 temporal resolution (Ming et al., 2005). This paper takes five Algerian expressways built by

107 China's Belt and Road Initiative Project as an example. We propose three different methods for

108 assessing indicator 9.1.1. The specific method objectives include: 1) Based on a large regional

109 scope, an evaluation method based on HRSL population data is proposed to evaluate and analyse

110 the contribution of five Algerian expressways built by China to the SDG-9.1.1 indicator in 2015.

111 2) Based on a medium-area scope, the NDBI building area population estimation method is used

112 to evaluate and analyse the rural population that resided within $2 \mathrm{~km}$ of a road in 2011, 2015 and

1132019 near the Bejaia-Hanif Expressway in Algeria. 3) Based on high-resolution remote sensing

114 monitoring, the population of Tikhramtath town, which is within $2 \mathrm{~km}$ of the Bejaia-Hanif

115 Expressway in Algeria, was assessed and analysed.

116

117 Research area and data

\section{Research area}

120

As part of China's Belt Project, five expressways have been built in Algeria (Table 1). The total length of the East-West Expressway in Algeria is $1216 \mathrm{~km}$, of which $528 \mathrm{~km}$ of the middle and western sections are under construction by China International Trust Co., Ltd. and China Railway Construction Co., Ltd. The project has adopted the engineering procurement construction contracting mode and European technical standards. The Tipaza Expressway is 48 $\mathrm{km}$ long and was built by the China Construction Fifth Engineering Bureau Co., Ltd. It will promote the development of tourism in the Tipaza area. The North-South Expressway is 3,000 $\mathrm{km}$ long, and the China Construction Company undertook the $53 \mathrm{~km}$ Chiffa to Berrouaghia section. It is the most difficult and complicated section of the North-South Expressway, containing nearly 100 bridges and 76 viaducts. The project will strategically connect Algeria with Niger, Nigeria and Chad. The full length of the Cherchell Ring Expressway is $17 \mathrm{~km}$, and it was built by the China Construction Company. The construction of the expressway greatly eased pressure on the N11 route and served as an extension of the $48 \mathrm{~km}$ expressway. The Bejaia Expressway is $100 \mathrm{~km}$ in length and was contracted by China Railway Construction. The connecting expressway project starts from the port of Bejaia in the north and connects to the East-West Expressway in the south. The project provides greater service to the port of Bejaia, while at the same time improving the local economy. The development has also eased traffic

138 congestion in the area (Fig. 1). The construction of the expressway has promoted the growth of 
139 Eastern and Western economies in Algeria (Tian \& Li, 2019), reduced the rate of traffic accidents, and formed a new space for social development (Bröcker, Dohse \& Rietveld, 2019).

141

142

\section{Research data}

143

144 This paper uses WorldPop and HRSL population raster data, Landsat remote sensing imagery, 145 Algerian urban area and administrative division map. The WorldPop project was launched in

1462013 as part of a global population mapping project led by the Institute of Geographical Data,

147 University of Southampton, UK (https://www.worldpop.org/). It aims to provide an open access

148 archive of spatial demographic datasets for Central and South America, Africa and Asia to

149 support development, disaster response and health applications. It uses raster prediction based on

150 a random forest model to generate a $100 \mathrm{~m}$ spatial resolution population density, which is then

151 used as a weighted surface and redistributed according to national population data (Stevens et al.,

152 2015). LandScan uses the National Imagery and Mapping Agency's (NIMA) Vector Map

153 (VMAP) series data and Digital Terrain Elevation Data (DTED) for global coverage of roads and

154 slopes, respectively (Bhaduri et al., 2002). HRSL population data has a resolution of $30 \mathrm{~m}$ and

155 was obtained from the Center for International Earth Science Information Network (CIESIN)

156 (Batran et al., 2018). Global Administrative Areas (GADM) is a database of the locations of the

157 world's administrative areas. Administrative areas in this database include countries, counties

158 and departments (Hijmans, Garcia \& Wieczorek, 2010). Landsat 5 and Landsat 8 data were

159 obtained from the US Geological Survey (Table 2; El-Askary et al., 2014). These data were

160 processed using several commands in ArcGIS 10.5 software.

161

162 Research methods

163 This paper aims to calculate the SDG 9.1.1 indicator in the proximity of five Algerian

164 expressways built as part of China's Belt and Road Initiative Project, from large to small areas.

165 Figure 2 presents a flowchart of the three methods. (1) Obtaining large-scale statistics based on

166 HRSL population data, using the nearest neighbor method and regional statistical method to

167 evaluate and analyse the contribution of five Algerian expressways to monitor indicator 9.1.1 in

168 the past five years; (2) For medium-sized areas, an evaluation method based on the NDBI

169 building area index is proposed. (3) For small areas, an evaluation method based on high-

170 resolution time series images is proposed. (4) analysis and comparison of the three population

171 statistics methods.

172 (1) A large-scale evaluation method for indicator 9.1.1. based on HRSL population raster data

173 In this paper, the population statistics of residents within two kilometers of five expressways are

174 studied using HRSL population data and nearest neighbor and regional statistics methods. The

175 nearest neighbor method locates the positions of pixels in the output image to the original image

176 by the nearest neighbor method. It finds the nearest pixel from the original image and takes the

177 value of the pixel as the value of the output image pixel. The nearest neighbor method is used to 
178 calculate the size of a single grid pixel. Then, by using the function of regional statistical

179 analysis, all the grid pixel values are tabulated and, finally, the sum of all pixel values is

180 calculated (Caraway, McCreight \& Rajagopalan, 2014; Rossi, Dungan \& Beck, 1994).

181 (2)Evaluation method of a medium area based on the NDBI building area index

182 The Middle Area comprises the Bejaia-Haniff Link Expressway in Algeria and uses the NDBI 183 building area population estimation method for demographic analysis. A two-kilometer NDBI

184 distribution map of the Bejaia-Haniff Link Expressway road was calculated using Landsat 185 remote sensing images from 2011, 2015, and 2019 and is presented in Fig. 3. The normalized

186 difference building index (NDBI) indicates the distribution of land for regional construction

187 (Zha, Ni \& Yang 2003; Li et al., 2017; Xu, 2008). The calculation method is shown in Equation

188 1. The NDBI is mainly used to extract information on buildings in cities and towns but,

189 according to Jin et al.'s (2019) research, it can also be used for villages and towns. There was a

190 significant positive correlation between the remote sensing index of village buildings and surface

191 temperature $(P<0.05)$. The Bejaia-Haniff Link Expressway has less urban area within $2 \mathrm{~km}$.

192 Most of the buildings are built in villages and towns. The article uses the city vector mask to

193 remove the extracted urban buildings and retain the villages and towns.

$$
N D B I=\frac{S M I R-N I R}{S M I R+N I R}
$$

195

196

197

198

199

200

201

202

203

204

205

206

207

208

209

210 NDBI was calculated using the Landsat-5 and Landsat-8 remote sensing image bands to extract

211 the area of rural buildings, and the area of rural buildings within two kilometers of the 
212 expressway in 2011, 2015 and 2019 was estimated. In order to maintain the accuracy of

213 extracting buildings and eliminate the effects of bare soil, cultivated land and water bodies, the

214 bare soil and cultivated land were extracted by the supervised classification maximum likelihood

215 method, while water bodies were extracted by visual interpretation. Finally, the NDBI was

216 masked by areas of bare soil, cultivated land and water bodies to obtain a map of the rural

217 building distribution. The total population is then calculated based on the total area of the

218 building and the per capita living area.

219 (3)Small-scale evaluation method based on high-resolution time series images

220 The small area of the town of Tikhramtath in the Bejaia-Haniff buffer zone of Algeria was

221 analysed in terms of demographics. A remote sensing method was used to monitor changes in

222 buildings in 2011, 2015, 2017 and 2019 in small areas according to a multi-time remote sensing

223 data map. A visual interpretation of the number of buildings and number of floors in the domains

224 was carried out through Google Earth $0.24 \mathrm{~m}$ high-resolution remote sensing images. First, the

225 building area was calculated with the Calculate Geometry tool. Then, according to the size of the

226 building, the population of each floor of each building was estimated to calculate the total

227 population of the area.

228 (4) Accuracy evaluation and comparative analysis

229 Comparisons of the populations and the results of the three methods presented in the article were 230 made. The root mean square error (RMSE) and relative RMSE (\%RMSE) were used to measure 231 the accuracy of Global Human Settlement (GHS) data with WorldPop data, HRSL data, NDBI 232 estimated building area data, and remote sensing visual interpretation data. The \% RMSE values 233 were obtained by dividing the RMSEs by the average of the number of censuses, which can 234 reflect the accuracy of the model simulation. Finally, the most suitable population calculation 235 methods for different regions were selected(Tan et al., 2017; Draperet al., 2013; Bhunia, Shit \& 236 Maiti, 2018).

$$
\operatorname{RMSE}=\sqrt{\frac{1}{\mathrm{~N}} \sum\left(\mathrm{f}_{\mathrm{i}}-\mathrm{r}_{\mathrm{i}}\right)^{2}}
$$

$$
\% \mathrm{RMSE}=\frac{\mathrm{RMSE}}{\frac{1}{\mathrm{~N}} \sum \mathrm{r}_{\mathrm{i}}}
$$

Where fi is the estimated value of the ith group of data, that is, the estimated population density obtained after population spatialization; ri is the reference value of the ith data, that is, the population density value obtained from the census data; $\mathrm{N}$ represents group data. 


\section{Experimental results}

244

245

246

\section{Algerian urban demographic results}

248

249

The statistics of the Algerian urban population are crucial to the statistics of the rural population.

250 The rural population size is based on the total population minus the urban population. The

251 distribution of the Algerian urban population from 2009 to 2019 is shown in Fig. 5. The sizes of

252 the urban population in 2009, 2011, 2013, 2015, 2017 and 2019 were 11,396,261, 11,857,311, $12,632,705,13,302,082,14,019,482$, and 14,820,436, respectively. In these years, the total rural population was $23,247,534,24,126,163,24,821,053,25,788,594,26,896,482$, and $28,158,778$ people.

According to the comparison of urban population changes, Fig. 6 shows that there are 84 cities in Algeria, five of which with an area of $200 \mathrm{~km}^{2}$ or more, all of which are located in the northern part of Algeria. The population of urban areas has grown rapidly over the last 10 years, with a total growth of 3,424,085 people. The urban areas along the new expressways are particularly obvious, including Oran, Algiers, Blida, Bouira, Sidi-Bel-Abbes and other larger cities.

262

\section{Demographic results of the provinces of Algeria}

264

265

Population data from the provinces of Algeria play an important role in calculating the proportion of the rural population that lives within $2 \mathrm{~km}$ of an expressway. Fig. 6 shows that the top three most populous provinces in Algeria are Algiers, Setif, and Oran, with populations of $3,037,455,1,510,132$ and 1,483,869, respectively. The three provinces with the smallest populations are Tindouf, Illizi, and Tamanghasset, with populations of 52,170, 54,636 and 181,217 , respectively. The population growth rate of each province is low. In 2009-2011, the

271 growth rate was above $10 \%$, being $12.678 \%$ in Tindouf Province. In 2011-2013, the growth rate

272 was above $10 \%$.

273

274 The provinces with growth rates $>10 \%$ during 2015-2017 were Naama Province, Tindouf

275 Province, and Tiaret Province, with growth rates of $11.132 \%, 12.678 \%$ and $17.411 \%$,

276 respectively. Tiziwuzu Province had the lowest growth rate at $0.516 \%$. The provinces with 
277 growth rates $>10 \%$ in $2017-2019$ were the same, with growth rates of $11.694 \%, 12.678 \%$ and

$27822.306 \%$, respectively, while Tiziwuzu Province had the lowest growth rate at $0.545 \%$ (Fig. 7).

279

280

\section{China's construction of five expressways in Algeria: SDG-9.1.1 assessment}

281

282

The Worldpop population raster data was counted as follows. (1) A expressway 2-km buffer

283 surface was created using tool "Feature to polygon" (2) Natural Earth urban area data was based

284 on the tool "Extract by mask" to obtain the urban population raster data, then the spatial analyze

285 tool "Raster calculator" was used to obtain the rural population raster map. (3) The generated

286

287 buffer surface was obtained using the "Extract by mask" tool to obtain 2-km rural population raster data. (4) The Worldpop cell raster layer was converted to a vector point layer through the "From raster to point tool" and the grid cell values were assigned to the point layer. (5) The required information was extracted from the point layer to a data table, then the population was counted (Tewari \& Manning, 2017; Holt et al., 2018).

The distribution of the rural population after China's construction of the Algeria expressway is shown in Fig. 8. The population of the Algeria Cherchell Ring Expressway is gradually increasing as shown in Table 3. Before the construction in 2011-2013, the growth rate was $1.77 \%$. The population increased rapidly after the start of construction and was $6.66 \%$ in 2015 . Population growth during the construction period was slower, dropping to $3.03 \%$, and then increased afterward. From the start of construction to two years later, there was an increase of 5,733 people. The population growth rate within $2 \mathrm{~km}$ of the $53 \mathrm{~km}$ North-South Expressway decreased by $0.22 \%$ in 2013 . After the start of construction, it gradually increased in 2017 . After construction, the growth will be slower. The $53 \mathrm{~km}$ north-south expressway in Algeria will increase by 3782 people from the start of construction to the second year after construction. The growth rate of the Bejaia-Haniff connection line of Algeria from pre-construction in 2011 to construction in 2015 gradually increased to $3.29 \%$, the growth rate in $2015-2017$ fell to $2.48 \%$, and the growth rate after construction was $2.65 \%$. The population increased by 15,825 during the Bejaia-Haniff Expressway construction period.

As shown in Table 4, the population near the Tipaza expressway decreased. After the project started, the growth rate increased rapidly to $5.84 \%$. During the construction process, the population growth rate dropped to $5.79 \%$. After construction, the growth rate reached $7.09 \%$ two years later in 2013. The growth rate dropped to $2.66 \%$ from 2013 to 2015 , and the population increased by 13,905 from the start to the end of construction. The growth rate of the Algeria

312 East-West Expressway gradually increased from 2005 to 2009 to $6.36 \%$. During the construction 313 process, the population growth rate dropped to $3.68 \%$. After completion of construction, the 
314 population growth rate was $4.85 \%$. The population increased by 156,755 people during the East-

315 West Expressway construction period. China's construction of five expressways in Algeria has

316 increased the rural population within the $2 \mathrm{~km}$ buffer zone by 196,000 in the eight years of

317 construction. By 2019 , the population increased by 252,687 , accounting for $9.16 \%$ of the rural

318 population. In 2009, 2011, 2013, 2015, 2017, 2019, the rural population within the $2 \mathrm{~km}$ buffer

319 zone accounted for $4.97 \%, 4.80 \%, 4.87 \%, 4.89 \%, 4.90 \%$, and $4.86 \%$ of the total rural

320 population, respectively.

321

322

\section{Large area range HRSL population raster data statistics results}

323

324

Tikhramtath town is located at the beginning of the Begaia Expressway and is the closest town to

it. The town's buildings are densely concentrated. The building numbers increased significantly

326 in $2011,2015,2017$, and 2019, making the town particularly suitable for small-area case

327 selection.

328

The large-area HRSL population raster data analysis method is used the nearest neighbor method to calculate the size of a single grid pixel. Then, by using the ArcGIS function of regional statistical analysis, all the HRSL population raster grid pixel values are tabulated and, finally, the sum of all pixel values is calculated.

The distribution of HRSL raster data for the rural population living within $2 \mathrm{~km}$ of an

335 expressway in 2015 is shown in Fig. 9. The populations of the Algeria East-West Expressway, Bejaia Expressway, Tipaza Expressway, North-South Expressway, and Cherchell Ring Expressway were $911,549,127,471,71,411,30,583$ and 41,657, respectively, accounting for approximately $4.12 \%$ of the 2015 rural population.

The population living within $2 \mathrm{~km}$ of the East-West Expressway was the largest of the five expressways, with a total population of 1,208,199, as shown in Table 5. The population distribution was closely related to the geography of Algeria. The northern part of Algeria comprises the coastal plains and hills of the Mediterranean coast, the central part is the Tele Atlas Mountains and Sahara Atlas Mountains, and the southern part of the Sahara desert is largely uninhabited. 
349 Fig. 10 shows that the building areas within $2 \mathrm{~km}$ of the Bejaia-Haniff Expressway in 2011, 2015 350 and 2019 were $15.84 \mathrm{~km}^{2}, 17.77 \mathrm{~km}^{2}$, and 21.77 $\mathrm{km}^{2}$, respectively in Algeria. By sampling 100 351 buildings to determine that the mean single building area is $290 \mathrm{~m}^{2}$, the rural populations in 3522011,2015 and 2019 are estimated to be $273,118,306,430$ and 375,408, respectively. They 353 accounted for $15.23 \%, 16.65 \%$, and $19.64 \%$ of the rural populations of Begaia, Buvira, and 354 Boumerdes provinces, respectively.

355

356

357

358

359

360

361

362

363

364

365

366

367

368

369

370

371

372

373

374

375

376

377

378

379

380

381

382

383

The rural population of the Bejaia-Haniff Expressway in Algeria had the largest population growth rate in 2019 of $22.51 \%$. Among them, the Tahalacht Industrial Zone in the northern part of the expressway, the Beni Mansour and the Tikhramtath town in the southern region, the Tala lbir town in the central region, Sidi Elash and Sidi Ayad have increased significantly.

\section{Estimated population by remote sensing monitoring of a small area}

Tikhramtath town is located at the beginning of the Begaia Expressway, the closest to the Begaia Expressway, and the towns and buildings are concentrated. The buildings increased significantly in 2011, 2015, 2017 and 2019, making it particularly suitable for small-area case selection.

The size of the building was vectored as a polygon feature by ArcGIS, then the ArcGIS tool "Calculate geometry" was used to calculate the area of the building. According to the 0.24-m high-resolution multi-time-series remote sensing image map, the number of building layers was compared with the image data of different periods. The number of layers of a single building was determined from the remote sensing image map. Finally, the layers of all buildings in Tikhramtath town were counted (Saadaoui et al., 2019).

A small area containing the town of Tikhramtath, within $2 \mathrm{~km}$ of the Bejay-Hanif Expressway in Algeria (before, during and after construction) was selected for demographic analysis. A map of the building distribution is shown in Fig. 11. The population of Tikhramtath town in 2011, 2015, 2017 and 2019 was $1,790,2,785,3,365$ and 3,970, respectively, accounting for $0.29 \%, 0.35 \%$, $0.52 \%$, and $0.60 \%$ of the total rural population in Buvira.

From the statistical chart, the size of buildings in the town of Tikhramtath within $2 \mathrm{~km}$ of the Bejaia-Hanif Expressway, the floor height, and the population of each floor of each building were estimated. The population of the Tikhramtath town in 2015, 2017 and 2019 is shown in Table 6. The growth rates in 2015, 2017 and 2019 were $55.59 \%, 20.83 \%$, and $15.01 \%$,

PeerJ reviewing PDF | (2019:09:41474:1:2:NEW 28 Feb 2020) 
384 respectively. The increase in population was mainly due to the construction of the Bejaia-Haniff 385 Expressway.

386

387 Discussion

388

389

390

391 (1)WorldPop and HRSL population statistics were used to compare regions around five

392 expressways built by China's Belt and Road Initiative Project in 2015. The results are shown in 393 Table 7.

394

395 The table shows that there is a small difference between the WorldPop demographic data and the 396 HRSL population data. The rural populations of the five expressways buffers differed by 1307 , $3975098,17,227,2706$, and 51,172.

398 (2) Comparison of the World Bank's WorldPop population statistics method, the NDBI building 399 area estimation method, and the HRSL population statistics method for the $2 \mathrm{~km}$ population of 400 the Bejaia-Hanif Expressway.

401 This paper uses the World Bank's WorldPop population statistics, the NDBI building area 402 estimation method, and HRSL population statistics to analyse the demographics of the Begaia403 Haniff Expressway in Algeria. The results are shown in Table 8.

According to the statistics, the WorldPop population data and NDBI building area population 406 estimates for 2011, 2015, and 2019 are quite different. The differences are 136,726, 161,732 and 223,191 , respectively. The difference between the WorldPop and HRSL population statistics is small, at 17,227. The NDBI building area population estimation method is subjective, and the total population can only be judged roughly, resulting in large errors. Worldpop demographics and HRSL demographics are also due to the small difference in statistical results due to 411 resolution issues.

412 (3) Table 9 compares the WorldPop population data and the small area remote sensing 413 monitoring method for Tikhramtath town.

414 Table 9 shows that the results of the three methods for Tikhramtath town are quite different. The 415 remote sensing monitoring visual interpretation method and WorldPop population statistics 416 differed by $1782,2766,3349$ and 3853 , respectively. The remote sensing monitoring visual 
417 interpretation method differed from the HRSL population statistics by 2,690 people. The

418 WorldPop population statistics are obviously inconsistent with the actual situation, while the

419 remote sensing monitoring visual interpretation method locates the added buildings.

420

421 This paper aims to calculate SDG indicator 9.1.1 in the proximity of five Algerian expressways.

422 The SDG-9.1.1 index represents the proportion of the rural population who live within $2 \mathrm{~km}$ of

423 an all-season road. At present, researchers in China and elsewhere have used many methods to

424 evaluate the SDG-9.1.1 indicator. Qiu et al. (2019), Bezuidenhoudt and Olympio (2019) and Xu,

425 Bai and Chen (2019) have proposed different methods. However, most of the above methods use 426 existing population data that is updated slowly, such that the new population cannot be found in

427 time. This paper proposes the use of remote sensing to monitor newly added buildings to

428 estimate the new rural population. This method makes up for the problem of the slow update of 429 existing population data.

430

\section{Precision verification}

432

433 We used GHS Population Grid data for accuracy verification. The GHS Population Grid is made

434 up of residential population estimates for target year 2015 provided by CIESIN GPWv4 435 (Gridded Population of the World, now in its fourth version). The estimates were disaggregated 436 from census or administrative units into grid cells, according to the distribution and density of 437 built-up areas as mapped in the GHSL global layer for the corresponding epoch. An accuracy 438 assessment table is shown in Table 10.

In the accuracy comparison, lower \%RMSE values indicate higher accuracy. The accuracy of the WorldPop population data in the large area was $89.99 \%$, which is slightly higher than the $81.02 \%$ accuracy of the HRSL population data. WorldPop population data was also most accurate in the middle region. The NDBI building area estimates are subjectively influenced by people and had the lowest accuracy of $2.58 \%$. The accuracy of the population data for Tikhramtath town (in the small area) was generally low and that of the HRSL population data was higher than that of the other two groups, at $12.34 \%$.

\section{Conclusions}


450 Figure 12 shows the rural population within $2 \mathrm{~km}$ of the five Algerian Expressways in 2009, $4512011,2013,2015,2017$, and 2019. It clearly shows that the rural population is greatest near the 452 East-West Expressway and lowest near the North-South Expressway. An abnormal point was 453 found. After searching, it was found that the population in 2009 was 31,842, indicating The rural 454 population growth rate was relatively fast in 2011. It was found that the longer the mileage of 455 rural roads, the greater the rural population within $2 \mathrm{~km}$ of a road.

456

457

458

459

460

461

462

463

464

465

466

467

468

469

470

471

472

473

474

475

476

477

478

479

480

481

482

483

484

485

486

The five expressways built by China's Belt and Road Initiative Project have led to increases in the rural populations on both sides of the roads. Cherchell Ring Expressway, the $53 \mathrm{~km}$ NorthSouth Expressway, Tipaza Expressway, Bejaia-Haniff Link Expressway, and East-West Expressway have driven rural population increases of 5733, 3782, 13,905, 15,825 and 196,000, respectively. The population of the $2 \mathrm{~km}$ buffer zone of the Bejaia-Haniff Expressway in Algeria in 2011,2015 and 2019 was $273,118,306,430$, and 375,408, respectively. The population of Tikhramtath in 2011, 2015, 2017 and 2019 was 1790, 2785, 3365, and 3970, respectively.

From large areas to small areas, different methods are suitable for road-wide demographic analysis: large- and medium-area demographics are suitable for WorldPop population statistics; while small-area demographics can use HRSL population raster data. The accuracy of the WorldPop population data in the largest area was $89.99 \%$, while that of the HRSL population data was $81.02 \%$. WorldPop population data was also most accurate in the middle region. The NDBI building area estimates had the lowest accuracy of $2.58 \%$. The HRSL population data was higher than that of the other two groups, at $12.34 \%$ in the small area.

The WorldPop dataset is updated annually. HRSL population data is only available from 2015 and it is not possible to obtain data on populations within $2 \mathrm{~km}$ of roads every year. Although the NDBI building area data and remote sensing visual interpretation data are of low precision, they are not affected by slow population data updating and can estimate the population according to remote sensing images in a timely manner.

Conflicts of Interest: The authors declare they have no conflicts of interest.

Author Contributions: Zhanhai Jia wrote the paper; Mingquan $\mathrm{Wu}$ and Zheng Niu gave comments and suggestions on the manuscript and checked the writing; Bin Tang and Yuxuan Mu analysed the data.

Funding:This work was supported by the Strategic Priority Research Program of Chinese Academy of Sciences (No. XDA19030304) and the Youth Innovation Promotion Association 
487 CAS (No. 2017089). The funders had no role in study design, data collection and analysis, 488 decision to publish, or preparation of the manuscript.

489

490

\section{References}

491 Chen J, Ren HR, Geng W, Peng S, and Ye F. 2018. Quantitative measurement and monitoring sustainable development goals (SDGs) with geospatial information. Geomat. World 25:1-7.

Commission UNS. 2017. Global indicator framework for the Sustainable Development Goals and targets of the 2030 Agenda for Sustainable Development. UN Resolution A/RES/71/313 (https://unstats un org/sdgs/indicators/Global Indicator Framework_A RES 71313 Annex pdf).

Bhattacharyay BN. 2015. 12 Strengthening Transport Infrastructure Connectivity Policies for Inclusive and Sustainable Asia. The Economics of Infrastructure Provisioning: The Changing

501 Role of the State:339.

503

504

Wei YQ, Li X, Gao F, Huang CL, Song XY, Wang B, Ma HQ, and Wang PL. 2018. The United Nations Sustainable Development Goals (SDG) and the Response Strategies of China. Advances in Earth Science 33:1084-1093.

Li HM, Wu MQ, Tian DH, Wu LX, and Niu Z. 2019. Monitoring and analysis of the expansion of the Ajmr Port, Davao City, Philippines using multi-source remote sensing data. PeerJ $511 \quad 7: \mathrm{e} 7512$.

512

513 Chen J, and Li Z. 2018. Chinese pilot project tracks progress towards SDGs. Nature 563:184.

514

Roberts P, Kc S, and Rastogi C. 2006. Rural access index: a key development indicator.

516

Mariathasan V, Bezuidenhoudt E, and Olympio KR. 2019. Evaluation of Earth Observation

Solutions for Namibia's SDG Monitoring System. Remote Sensing 11:1612.

Qiu Y, Zhao X, Fan D, and Li S. 2019. Geospatial Disaggregation of Population Data in Supporting SDG Assessments: A Case Study from Deqing County, China. ISPRS International Journal of Geo-Information 8:356.

523

524 Frensis B, 2018 Using innovative methods to report against the Sustainable Development Goals 525 Available at http://www.italianplants.com (accessed 22 December 2019). 
527 Ming DP, Luo JC, Shen ZF, Wang M, and Sehng H. 2005. Research on information extraction

528 and target recognition from high resolution remote sensing image. Cehui Kexue/ Science of

529 Surveying and Mapping 30:18-20.

530

531 Tian G, and Li J. 2019. How Does Infrastructure Construction Affect Economic Development

532 along the "Belt and Road": By Promoting Growth or Improving Distribution? Emerging Markets

533 Finance and Trade:1-17.

534

535 Bröcker J, Dohse D, and Rietveld P. 2019. Infrastructure and regional development. Handbook

536 of regional growth and development theories: Edward Elgar Publishing.

537

538 Stevens FR, Gaughan AE, Linard C, and Tatem AJ. 2015. Disaggregating census data for

539 population mapping using random forests with remotely-sensed and ancillary data. PloS one

540 10:e0107042.

541

542

543

544

Bhaduri B, Bright E, Coleman P, and Dobson J. 2002. LandScan. Geoinformatics 5:34-37.

545

Batran M, Mejia M, Kanasugi H, Sekimoto Y, and Shibasaki R. 2018. Inferencing human

546 spatiotemporal mobility in greater Maputo via mobile phone big data mining. ISPRS

547

548 Hijmans R, Garcia N, and Wieczorek J. 2010. GADM database of Global Administrative Areas.

549 Version.

550

551

El-Askary H, Abd El-Mawla S, Li J, El-Hattab M, and El-Raey M. 2014. Change detection of

552 coral reef habitat using Landsat-5 TM, Landsat 7 ETM+ and Landsat 8 OLI data in the Red Sea

553

554

555

556

557 (Hurghada, Egypt). International journal of remote sensing 35:2327-2346.

Caraway NM, McCreight JL, and Rajagopalan B. 2014. Multisite stochastic weather generation using cluster analysis and k-nearest neighbor time series resampling. Journal of hydrology 508:197-213.

558

559 Rossi RE, Dungan JL, and Beck LR. 1994. Kriging in the shadows: geostatistical interpolation

560 for remote sensing. Remote Sensing of Environment 49:32-40.

561

562

Zha Y, Ni SX, and Yang S. 2003. An effective approach to automatically extract urban land-use 563 from TM imagery. JOURNAL OF REMOTE SENSING-BEIJING- 7:37-40.

564

565

Li H, Wang C, Zhong C, Su A, Xiong C, Wang J, and Liu J. 2017. Mapping urban bare land

566 automatically from Landsat imagery with a simple index. Remote Sensing 9:249. 
567

$568 \mathrm{Xu} \mathrm{H.} \mathrm{2008.} \mathrm{A} \mathrm{new} \mathrm{index} \mathrm{for} \mathrm{delineating} \mathrm{built-up} \mathrm{land} \mathrm{features} \mathrm{in} \mathrm{satellite} \mathrm{imagery.} \mathrm{International}$

569 Journal of Remote Sensing 29:4269-4276.

570

571

572

573

574

575

576

577

578

579

580

581

582

583

584

585

586

587

588

589

590

591

592

593

594

595

596

597

598

599

600

601

602

603

604

605

Jin JL, Sun J, Yang LB, Dong CF, Qi F. 2019 Correlation between the remote sensing index of the underlying surface and the surface temperature in the villages in Hangzhou[J]. Journal of Zhejiang A\&F University.

Cabral AI, Silva S, Silva PC, Vanneschi L, and Vasconcelos MJ. 2018. Burned area estimations derived from Landsat ETM+ and OLI data: comparing genetic programming with maximum likelihood and classification and regression trees. ISPRS journal of photogrammetry and remote sensing 142:94-105.

Murthy C, Raju P, and Badrinath K. 2003. Classification of wheat crop with multi-temporal images: Performance of maximum likelihood and artificial neural networks. International Journal of Remote Sensing 24:4871-4890.

Otukei JR, and Blaschke T. 2010. Land cover change assessment using decision trees, support vector machines and maximum likelihood classification algorithms. International Journal of Applied Earth Observation and Geoinformation 12:S27-S31.

Keuchel J, Naumann S, Heiler M, and Siegmund A. 2003. Automatic land cover analysis for Tenerife by supervised classification using remotely sensed data. Remote Sensing of Environment 86:530-541.

Li C, Wang J, Wang L, Hu L, and Gong P. 2014. Comparison of classification algorithms and training sample sizes in urban land classification with Landsat thematic mapper imagery. Remote Sensing 6:964-983.

Zhang X, Zhang M, Zheng Y, and Wu B. 2016. Crop mapping using PROBA-V time series data at the Yucheng and Hongxing farm in China. Remote Sensing 8:915.

Pujiono E, Sadono R, Hartono H, and Imron MA. 2019. A Three Decades Assessment of Forest Cover Changes in The Mountainous Tropical Forest of Timor Island, Indonesia. Jurnal Manajemen Hutan Tropika 25:51-64.

Tan M, Liu K, Liu L, Zhu Y, and Wang D. 2017. Spatialization of population in the Pearl River Delta in $30 \mathrm{~m}$ grids using random forest model. PROGRESS IN GEOGRAPHY.

Peer] reviewing PDF | (2019:09:41474:1:2:NEW 28 Feb 2020) 
606 Draper C, Reichle R, de Jeu R, Naeimi V, Parinussa R, and Wagner W. 2013. Estimating root 607 mean square errors in remotely sensed soil moisture over continental scale domains. Remote 608 Sensing of Environment 137:288-298.

609

610 Bhunia GS, Shit PK, and Maiti R. 2018. Comparison of GIS-based interpolation methods for 611 spatial distribution of soil organic carbon (SOC). Journal of the Saudi Society of Agricultural 612 Sciences 17:114-126.

613

614 Tewari S, and Manning F. 2017. Identifying Corrosion Zones in Coastal Regions for Metal 615 Pipes-A GIS Approach. Pipelines 2017, 618-625.

616

617 Holt CDS, Nevin OT, Smith D, and Convery I. 2018. Environmental niche overlap between

618 snow leopard and four prey species in Kazakhstan. Ecological informatics 48:97-103.

619

620

Saadaoui H, Ghennioui A, Ikken B, Rhinane H, and Maanan M. 2019. Using GIS and

621 photogrammetry for assessing solar photovoltaic potential on Flat Roofs in urban area case of the

622 city of Ben Guerir/Morocco. International Archives of the Photogrammetry, Remote Sensing and 623 Spatial Information Sciences 42.

624

625

626 
Figure 1

Study area location maps.

(a) Tipaza Expressway, (b) Cherchell Ring Expressway, (c) North-South Expressway, (d) all five highways, (e) East-West Expressway, (f) Bejaia Expressway. 


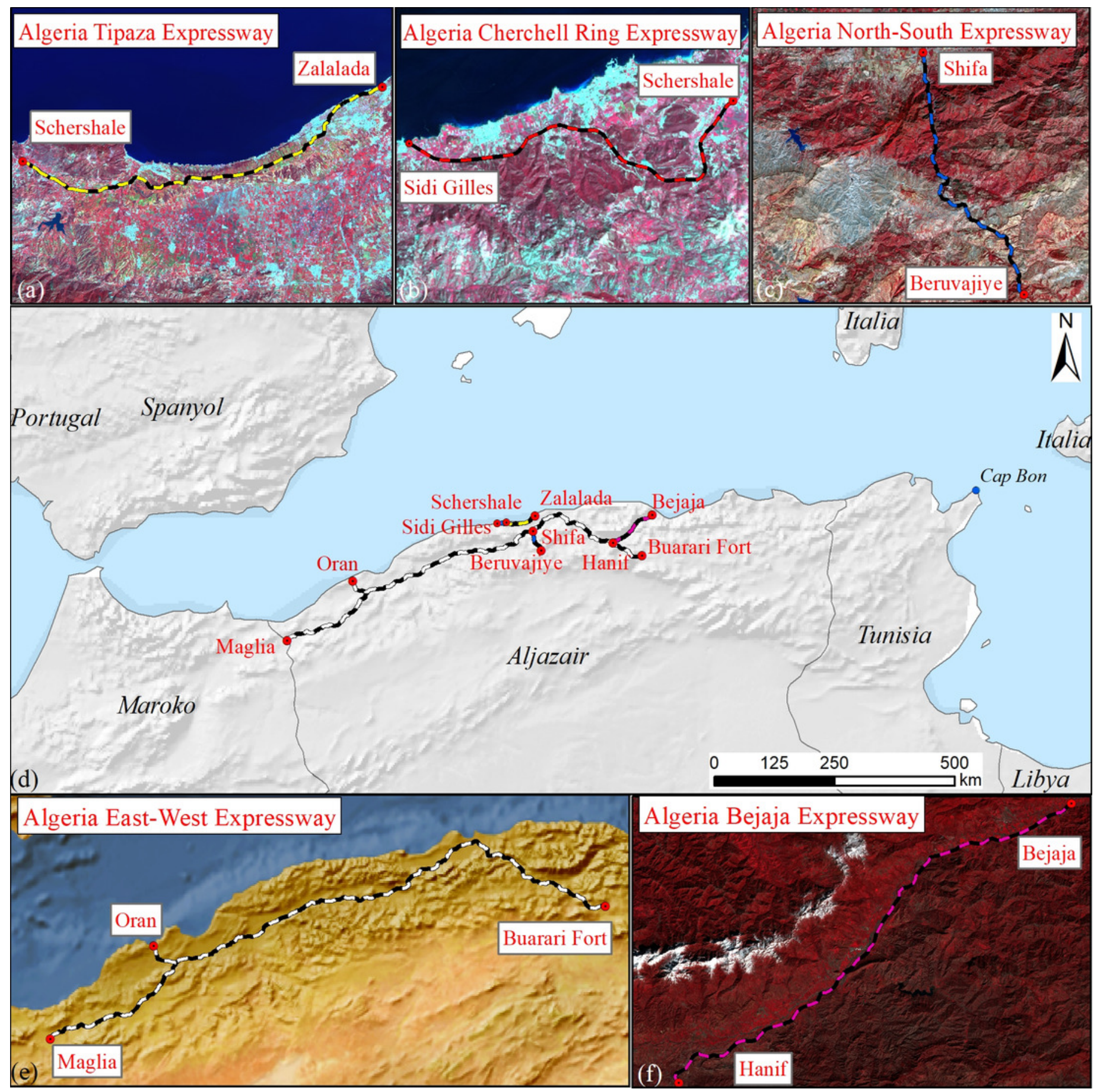


Figure 2

\section{Flow chart of the three methods.}

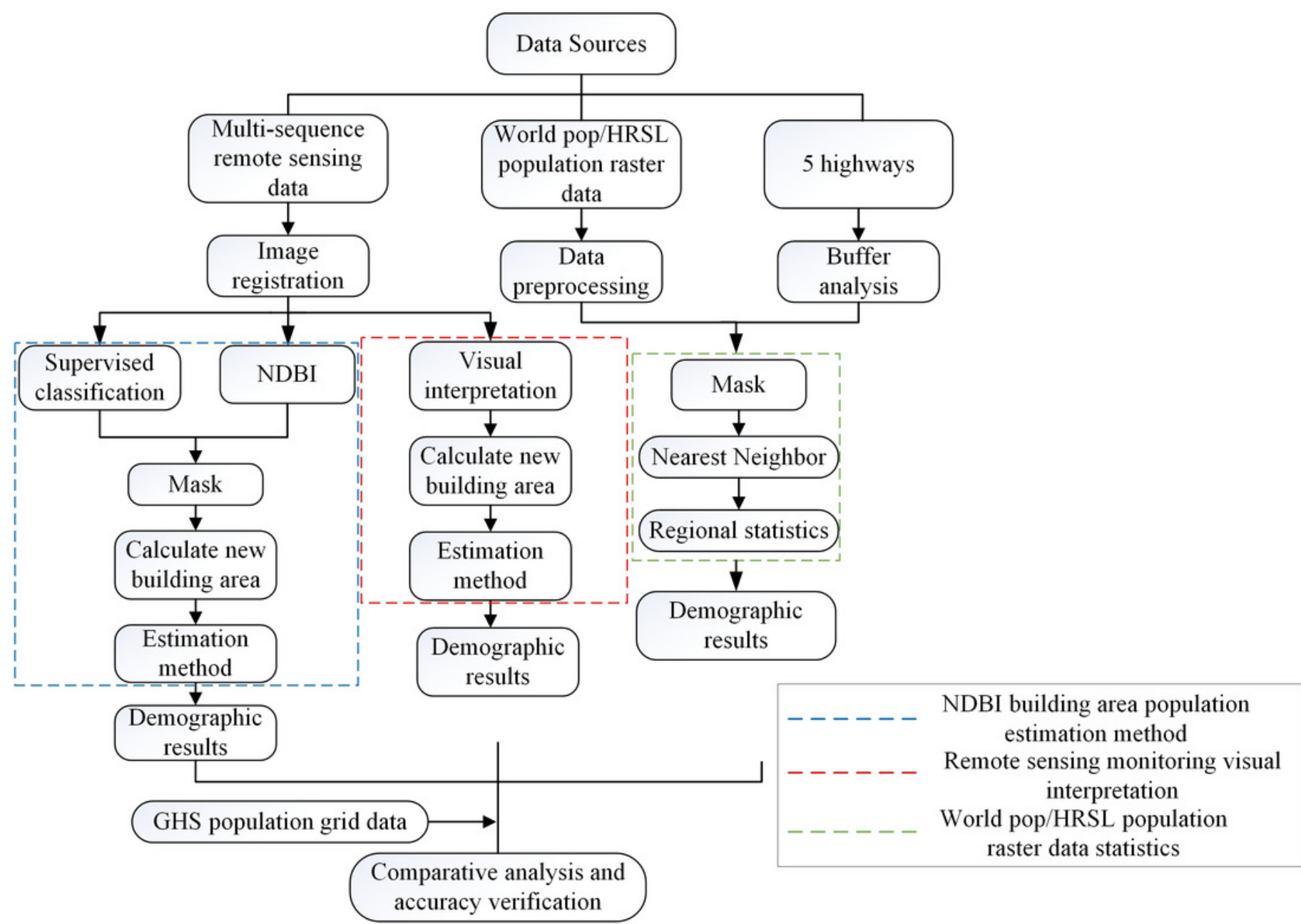




\section{Figure 3}

\section{1, 2015, 2019 NDBI.}

(a) Schematic diagram of the local study area, (b) 2011 Landsat remote sensing image map,

(c) 2011 NDBI map, (d) 2015 Landsat remote sensing image map, (e) 2015 NDBI map,

(f)2019 Landsat remote sensing image map, (g) 2019 NDBI map.
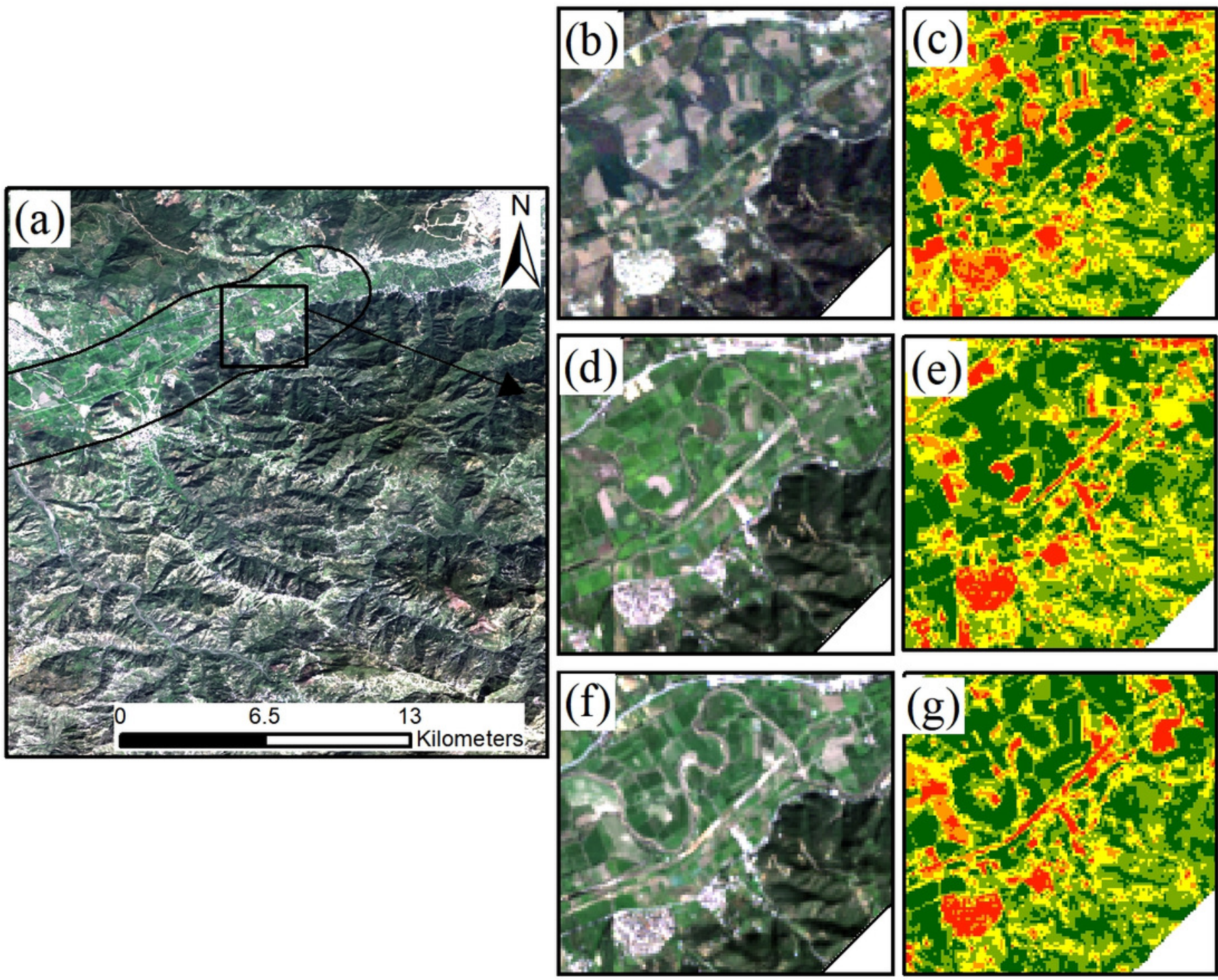
Figure 4

Supervised classification sample

(a) Urben and rural areas sample. (b) Urban and rural verification images. (c) Woodland sample. (c) Woodland verification images. (d) Arable land sample. (d) Arable land verification images. (e) Bare land sample. (f) Bare land verification images. 


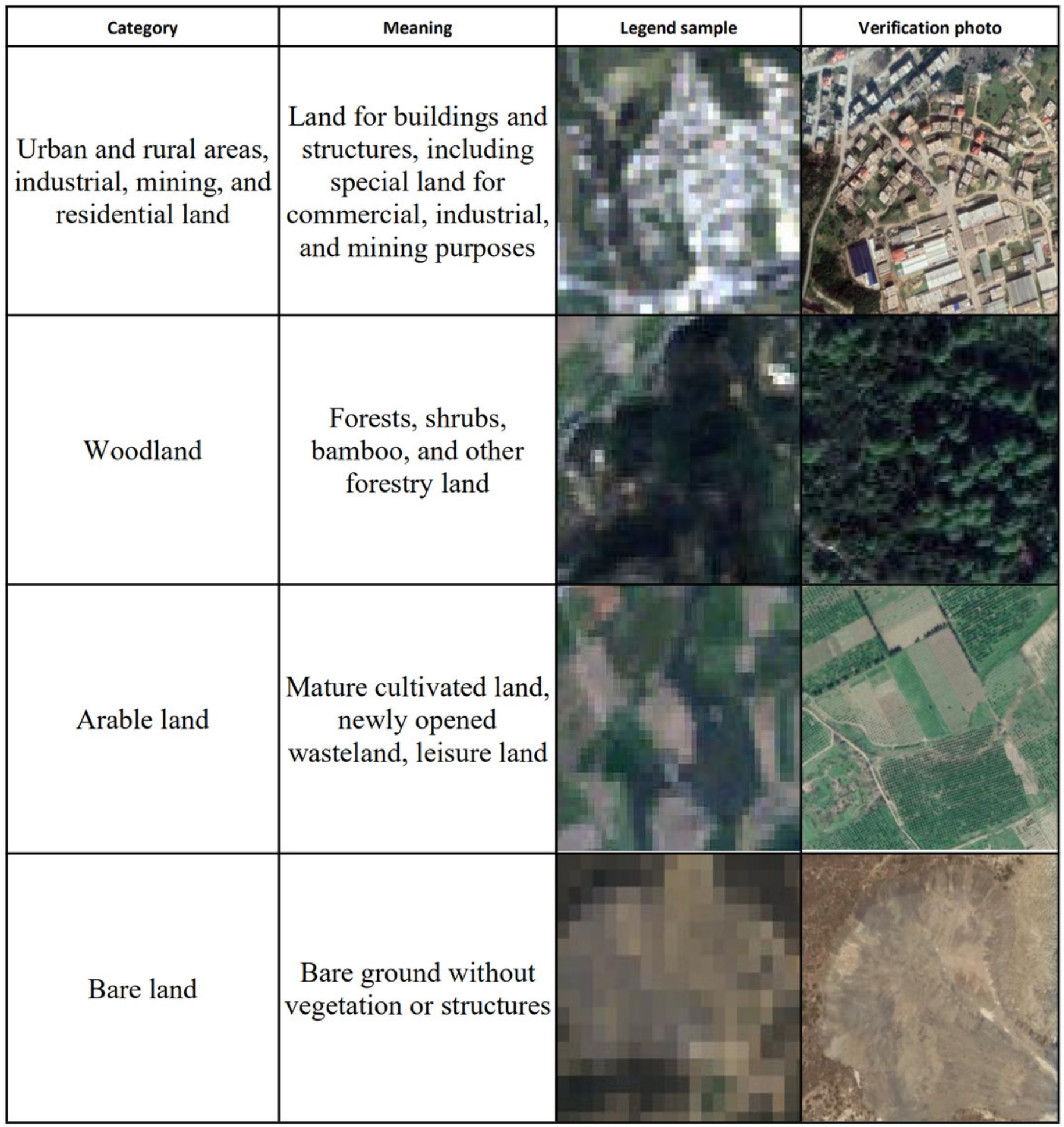


Figure 5

Algerian urban population map.

(a) 2009, (b) 2011, (c) 2013, (d) 2015, (e) 2017, and (f) 2019.
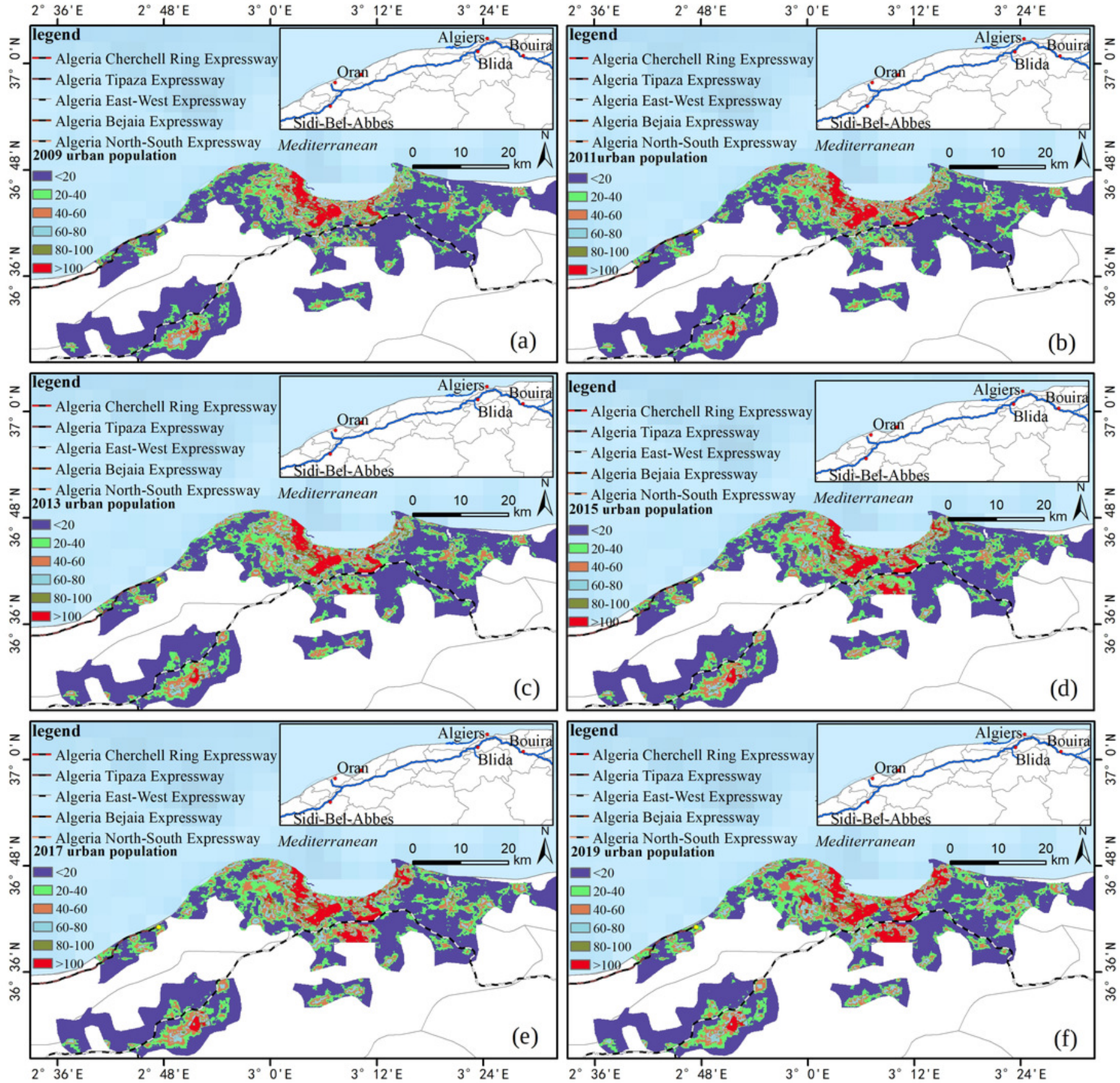


\section{Figure 6}

\section{Demographic changes in the provinces of Algeria.}

\section{(a) Population in 2009๑2011 and 2013, (b) Growth rate in 2011 and 2013.}

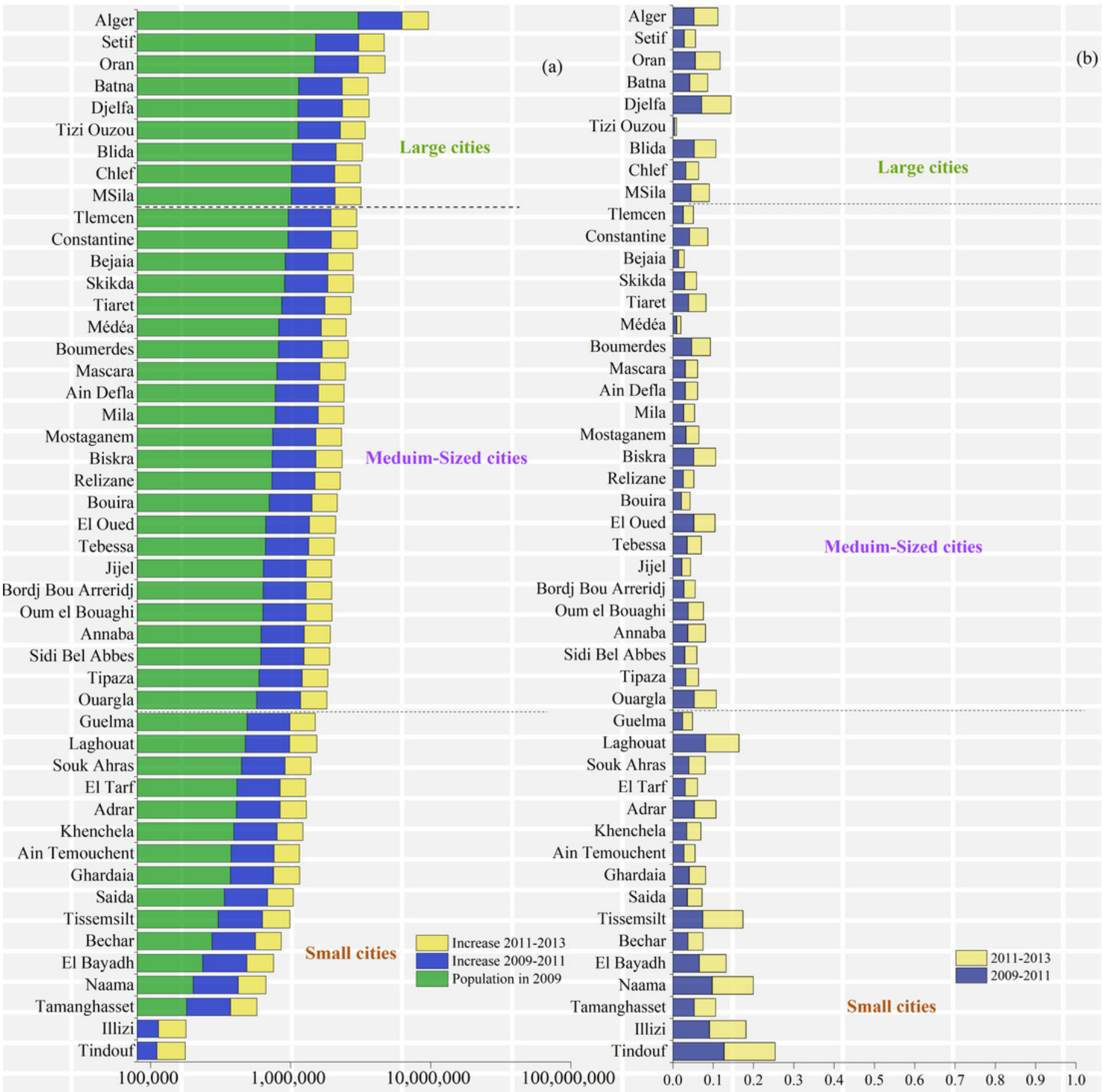




\section{Figure 7}

\section{Demographic changes in the provinces of Algeria.}

\section{(a) Population in 2015, 2017 and 2019, (b) Growth rate in 2017 and 2019.}

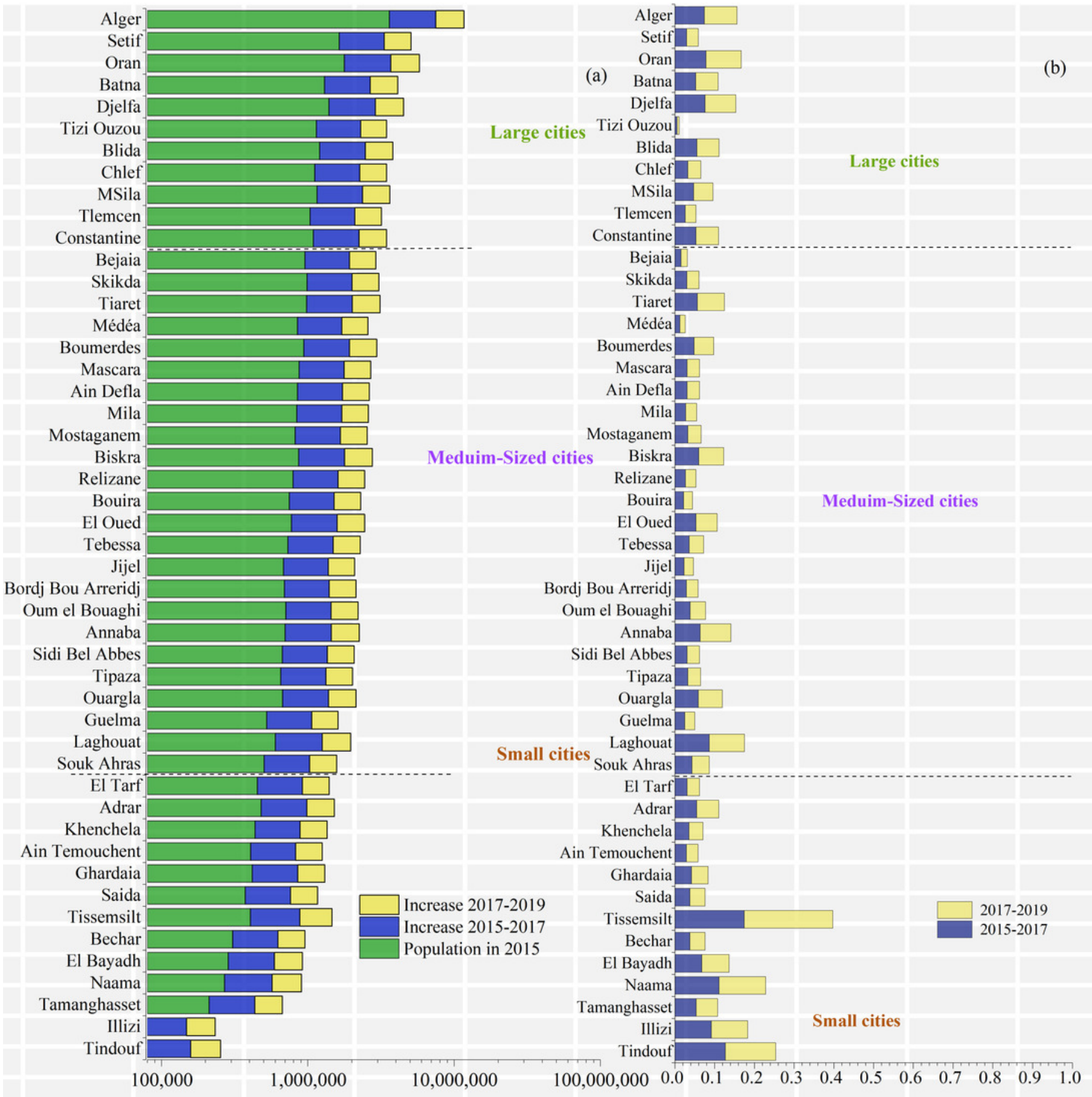


Figure 8

Population distribution within the $2 \mathrm{~km}$ bufffer zone of five Algerian highways constructed by China.

(a) 2009, (b) 2011, (c) 2013, (d) 2015, (e) 2017, and (f) 2019. 

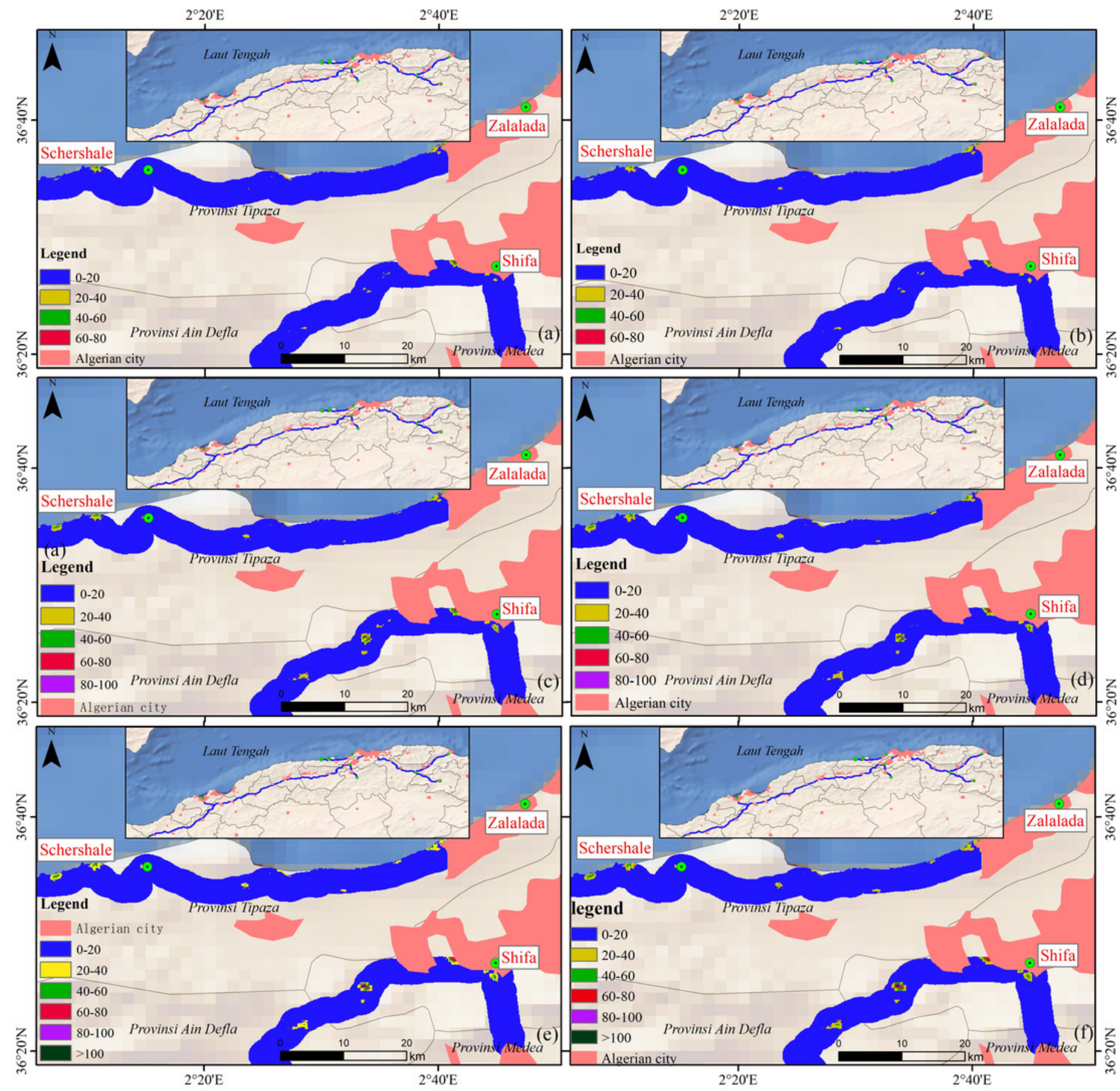
Figure 9

Distribution of rural HRSL population data within $2 \mathrm{~km}$ of highways in 2015.

(a) Bejaia Expressway, (b) Tipaza Expressway, (c) Cherchell Ring Expressway, (d) NorthSouth Expressway, (e) East-West Expressway. 


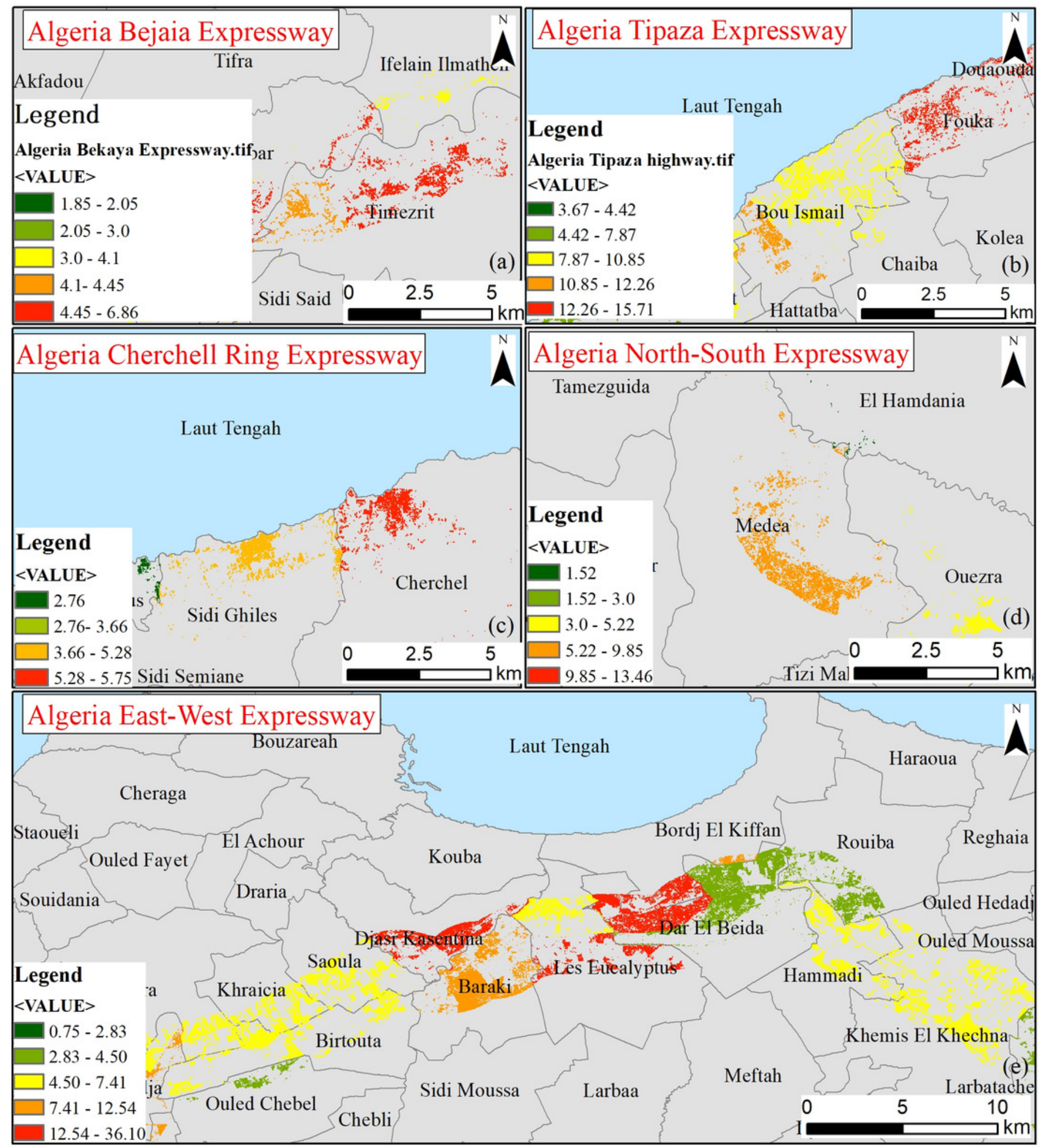


Figure 10

NDBI extraction of rural buildings within $2 \mathrm{~km}$ of the Bejaia Expressway.

(a) 2011, (b) 2015, and (c) 2019 . 

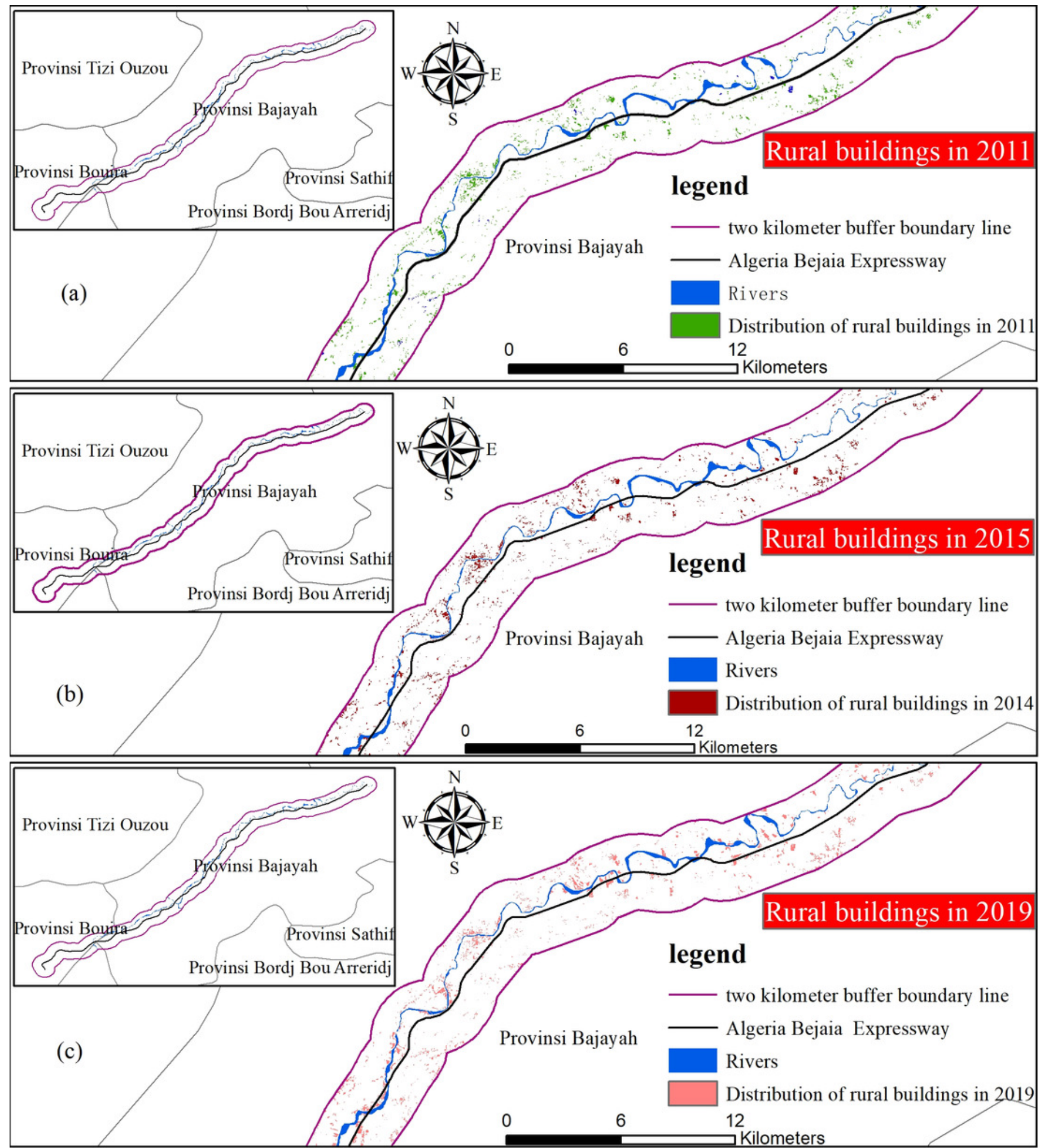
Figure 11

Remote sensing monitoring of the building distribution in Tikhramtath town.

(a) 2011, (b) 2011 and 2015, (c) 2011, 2015 and 2017, and (d) 2011, 2015, 2017, and 2019.

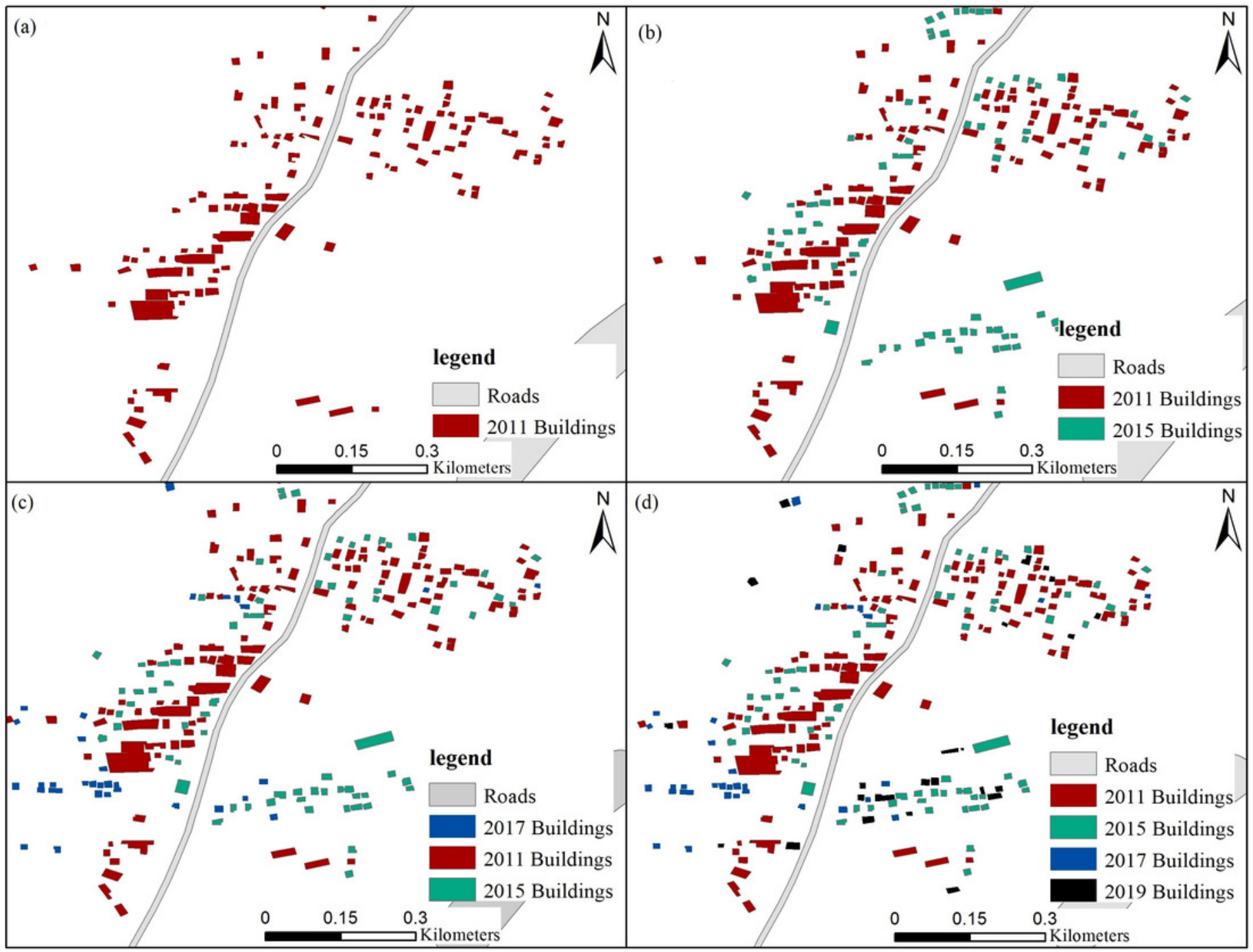


Figure 12

The rural population within 2 kilometers of 5 Algerian Expressways in 2009, 2011, 2013, 2015, 2017, and 2019.

(a) Cherchell Ring Expressway and North- South Expressway, (b) Tipaza Expressway and Bejaia Expressway, (c) East-West Expressway.
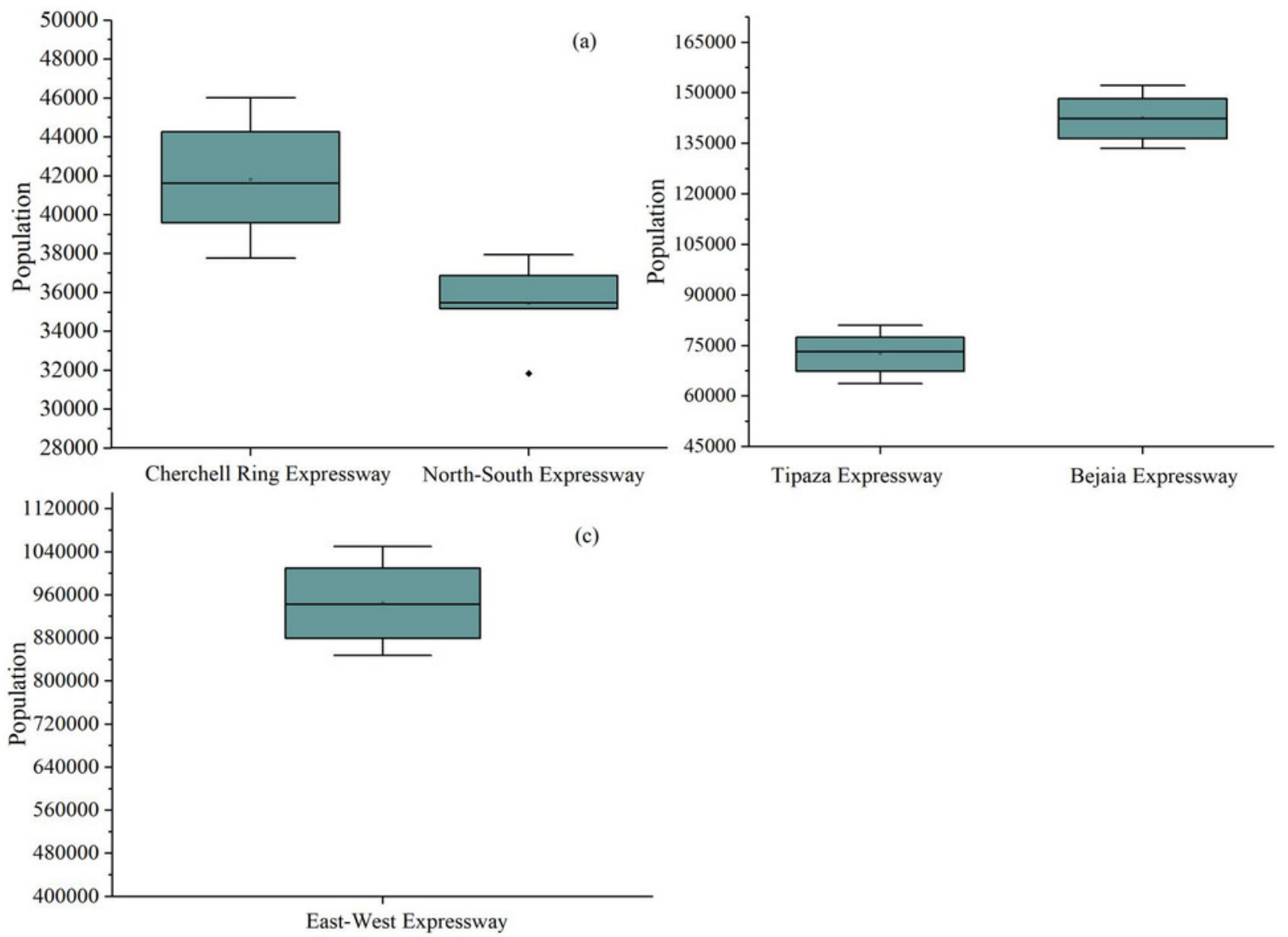

(b) 
Table $\mathbf{1}$ (on next page)

China's Belt and Road Expressway in Algeria. 


\begin{tabular}{|c|c|c|c|c|c|c|c|}
\hline $\begin{array}{c}\text { Contine } \\
\mathrm{nt}\end{array}$ & $\begin{array}{l}\text { Coun } \\
\text { try }\end{array}$ & $\begin{array}{l}\text { Highway } \\
\text { name }\end{array}$ & Chinese company & $\begin{array}{c}\text { Line } \\
\text { lengt } \\
\mathrm{h} \\
(\mathrm{km})\end{array}$ & $\begin{array}{c}\text { Constr } \\
\text { uction } \\
\text { start } \\
\text { year }\end{array}$ & $\begin{array}{l}\text { Constru } \\
\text { ction } \\
\text { end year } \\
\text { or } \\
\text { duration }\end{array}$ & $\begin{array}{l}\text { Mode of cooperation } \\
\text { (investment, } \\
\text { construction, } \\
\text { acquisition) }\end{array}$ \\
\hline Africa & $\begin{array}{l}\text { Alge } \\
\text { ria }\end{array}$ & $\begin{array}{l}\text { East-West } \\
\text { Expressway }\end{array}$ & $\begin{array}{l}\text { China Railway } \\
\text { Construction 17th } \\
\text { Bureau, China } \\
\text { International Trust, } \\
\text { and Investment }\end{array}$ & 528 & 2006 & 2012 & Joint construction \\
\hline Africa & $\begin{array}{l}\text { Alge } \\
\text { ria }\end{array}$ & $\begin{array}{c}\text { Tipaza } \\
\text { Expressway }\end{array}$ & $\begin{array}{l}\text { China Construction } \\
\text { Fifth Bureau }\end{array}$ & 48 & 2008 & 2011 & Contract construction \\
\hline Africa & $\begin{array}{l}\text { Alge } \\
\text { ria }\end{array}$ & $\begin{array}{c}\text { North- } \\
\text { South } \\
\text { Expressway }\end{array}$ & $\begin{array}{c}\text { China Construction } \\
\text { Corporation }\end{array}$ & 53 & 2012 & 2015 & Joint construction \\
\hline Africa & $\begin{array}{l}\text { Alge } \\
\text { ria }\end{array}$ & $\begin{array}{l}\text { Cherchell } \\
\text { Ring } \\
\text { Expressway }\end{array}$ & $\begin{array}{c}\text { China Construction } \\
\text { Corporation }\end{array}$ & 17 & 2014 & 2018 & Contract construction \\
\hline Africa & $\begin{array}{l}\text { Alge } \\
\text { ria }\end{array}$ & $\begin{array}{c}\text { Bejaia } \\
\text { Expressway }\end{array}$ & $\begin{array}{c}\text { China Construction } \\
\text { Corporation }\end{array}$ & 100 & 2013 & 2017 & Contract construction \\
\hline
\end{tabular}


Table 2 (on next page)

Data sources. 


\begin{tabular}{|c|c|c|c|c|}
\hline Data & Source & Dates & Internet link & Spatial resolution \\
\hline $\begin{array}{l}\text { World } \\
\text { population } \\
\text { raster data }\end{array}$ & HRSL & 2015 & $\begin{array}{c}\text { https://www.ciesin.columbia.edu/da } \\
\text { ta/hrsl/\#data }\end{array}$ & $30 \mathrm{~m}$ \\
\hline $\begin{array}{l}\text { World } \\
\text { population } \\
\text { raster data }\end{array}$ & WorldPop & 2010-2019 & http://www.worldpop.org.uk/ & $100 \mathrm{~m}$ \\
\hline $\begin{array}{l}\text { World } \\
\text { population } \\
\text { raster data }\end{array}$ & GHS & 2015 & $\begin{array}{c}\text { https://ghslsys.jrc.ec.europa.eu/datas } \\
\text { ets.php\#2016public }\end{array}$ & $250 \mathrm{~m}$ \\
\hline Urban area & Natura Earth & 2018 & http://www.naturalearthdata.com & $10 \mathrm{~m}$ \\
\hline $\begin{array}{l}\text { Remote sensing } \\
\text { image }\end{array}$ & $\begin{array}{c}\text { Landsat } 5 \\
\text { and Landsat } \\
8\end{array}$ & $\begin{array}{c}2011 \\
2015,2019\end{array}$ & http://earthexplorer.usgs.gov & $30 \mathrm{~m}$ \\
\hline $\begin{array}{l}\text { Administrative } \\
\text { division map }\end{array}$ & GADM & 2018 & $\begin{array}{c}\text { https://gadm.org/download_country } \\
\text { _v3.html }\end{array}$ & Level-City \\
\hline
\end{tabular}


Table 3 (on next page)

Statistics of highway populations. 


\begin{tabular}{lcccccc}
\hline Year & \multicolumn{2}{c}{$\begin{array}{c}\text { Cherchell } \\
\text { Ring } \\
\text { Expressway } \\
\text { population }\end{array}$} & $\begin{array}{c}\text { Growth North-South Growth } \\
\text { rate }\end{array}$ & $\begin{array}{c}\text { Expressway } \\
\text { population }\end{array}$ & Bejaia & Growth \\
& Expressway & rate \\
population & & \\
\hline $\begin{array}{l}2011 \text { (before } \\
\text { construction) }\end{array}$ & 39,581 & $4.82 \%$ & 35,168 & $10.45 \%$ & 136,392 & $2.18 \%$ \\
$\begin{array}{l}2013 \text { (before } \\
\text { construction) }\end{array}$ & 40,282 & $1.77 \%$ & 35,246 & $0.22 \%$ & 140,084 & $2.71 \%$ \\
$\begin{array}{l}\text { 2015 (under } \\
\text { construction) }\end{array}$ & 42,964 & $6.66 \%$ & 35,681 & $1.23 \%$ & 144,698 & $3.29 \%$ \\
$\begin{array}{l}2017 \text { (under } \\
\text { construction) }\end{array}$ & 44,265 & $3.03 \%$ & 36,883 & $3.37 \%$ & 148,286 & $2.48 \%$ \\
2019 (after construction) & 46,015 & $3.95 \%$ & 37,950 & $2.89 \%$ & 152,217 & $2.65 \%$ \\
\hline
\end{tabular}


Table 4 (on next page)

Statistics of the highway populations. 


\begin{tabular}{lcccc}
\hline Year & $\begin{array}{c}\text { Tipaza } 48 \text { km highway } \\
\text { population }\end{array}$ & Growth rate & $\begin{array}{c}\text { East-West } \\
\text { Expressway } \\
\text { population }\end{array}$ & $\begin{array}{c}\text { Growth } \\
\text { rate }\end{array}$ \\
\hline $\begin{array}{l}2005 \text { (before } \\
\text { construction) }\end{array}$ & 60,320 & $3.70 \%$ & 764,851 & $3.61 \%$ \\
$\begin{array}{l}2007 \text { (before } \\
\text { construction) }\end{array}$ & 60,212 & $-0.18 \%$ & 797,051 & $4.21 \%$ \\
$\begin{array}{l}2009 \text { (under } \\
\text { construction) }\end{array}$ & 63,729 & $5.84 \%$ & 847,763 & $6.36 \%$ \\
$\begin{array}{l}2011 \text { (under } \\
\text { construction) }\end{array}$ & 67,419 & $5.79 \%$ & 878,946 & $3.68 \%$ \\
$\begin{array}{l}2013 \text { (after } \\
\text { construction) }\end{array}$ & 72,200 & $7.09 \%$ & 921,606 & $4.85 \%$ \\
\hline
\end{tabular}




\section{Table 5 (on next page)}

HRSL population statistics within $2 \mathrm{~km}$ of highways in 2015 . 


\begin{tabular}{lccc}
\hline Highway & Rural population & Urban population & Total population \\
\hline Cherchell Ring Road & 41,657 & 0 & 41,657 \\
North-South Expressway & 30,583 & 19,844 & 50,427 \\
Bejaia Expressway & 127,471 & 19,136 & 146,607 \\
Tipaza 48 km highway & 71,411 & 17,336 & 88,747 \\
East-West Expressway & 911,549 & 296,650 & $1,208,199$ \\
\hline
\end{tabular}

1 
Table 6(on next page)

Population of Tikhramtath town according to building characteristics, 2011 - 2019. 


\begin{tabular}{|c|c|c|c|c|c|c|c|c|c|c|c|c|c|}
\hline \multirow[b]{2}{*}{$\begin{array}{l}\text { Buildi } \\
\text { ng } \\
\text { area } \\
(\mathrm{m} 2)\end{array}$} & \multicolumn{3}{|c|}{2011} & \multicolumn{3}{|c|}{2015} & \multicolumn{3}{|c|}{2017} & \multicolumn{3}{|c|}{2019} & \multirow[b]{2}{*}{$\begin{array}{c}\text { Populati } \\
\text { on per } \\
\text { floor }\end{array}$} \\
\hline & \begin{tabular}{|c|}
$1-$ \\
floor \\
buildi \\
ngs \\
\end{tabular} & $\begin{array}{c}2- \\
\text { floor } \\
\text { buildi } \\
\text { ngs }\end{array}$ & $\begin{array}{c}3- \\
\text { floor } \\
\text { buildi } \\
\text { ngs }\end{array}$ & $\begin{array}{c}1- \\
\text { floor } \\
\text { buildi } \\
\text { ngs } \\
\end{array}$ & $\begin{array}{c}2- \\
\text { floor } \\
\text { buildi } \\
\text { ngs }\end{array}$ & $\begin{array}{c}3- \\
\text { floor } \\
\text { buildi } \\
\text { ngs }\end{array}$ & $\begin{array}{c}1- \\
\text { floor } \\
\text { buildi } \\
\text { ngs }\end{array}$ & $\begin{array}{c}2- \\
\text { floor } \\
\text { buildi } \\
\text { ngs }\end{array}$ & $\begin{array}{c}\text { 3- } \\
\text { floor } \\
\text { buildi } \\
\text { ngs }\end{array}$ & $\begin{array}{c}1- \\
\text { floor } \\
\text { buildi } \\
\text { ngs }\end{array}$ & $\begin{array}{c}2- \\
\text { floor } \\
\text { buildi } \\
\text { ngs }\end{array}$ & $\begin{array}{c}3- \\
\text { floor } \\
\text { buildi } \\
\text { ngs } \\
\end{array}$ & \\
\hline $0-150$ & 18 & 0 & 0 & 31 & 0 & 0 & 37 & 0 & 0 & 42 & 0 & 0 & 5 \\
\hline $\begin{array}{c}150- \\
300\end{array}$ & 57 & 4 & 0 & 124 & 6 & 1 & 145 & 11 & 1 & 159 & 11 & 1 & 10 \\
\hline $\begin{array}{c}300- \\
600\end{array}$ & 28 & 3 & 0 & 34 & 3 & 0 & 42 & 3 & 0 & 58 & 3 & 0 & 15 \\
\hline$>600$ & 17 & 2 & 2 & 22 & 2 & 2 & 28 & 2 & 2 & 33 & 2 & 2 & 20 \\
\hline $\begin{array}{l}\text { Total } \\
\text { popul } \\
\text { ation }\end{array}$ & & 1790 & & & 2785 & & & 3365 & & & 3870 & & \\
\hline
\end{tabular}


Table 7 (on next page)

WorldPop and HRSL population statistics. 


\begin{tabular}{lcc}
\hline Region & $\begin{array}{c}\text { WorldPop population statistics } \\
\text { (persons) }\end{array}$ & $\begin{array}{c}\text { HRSL population } \\
\text { statistics (persons) }\end{array}$ \\
\hline $\begin{array}{l}\text { Cherchell Ring } \\
\text { Expressway }\end{array}$ & 42,964 & 41,657 \\
North-South Expressway & 35,681 & 30,583 \\
Bejaia Expressway & 144,698 & 127,471 \\
Tipaza Expressway & 74,117 & 71,411 \\
East-West Expressway & 962,721 & 911,549 \\
\hline
\end{tabular}


Table 8(on next page)

WorldPop, NDBI and HRSL population statistics. 


\begin{tabular}{lccc}
\hline Time & $\begin{array}{c}\text { WorldPop } \\
\text { population } \\
\text { statistics }\end{array}$ & $\begin{array}{c}\text { NDBI building area } \\
\text { population estimation } \\
\text { method }\end{array}$ & $\begin{array}{c}\text { HRSL population } \\
\text { statistics }\end{array}$ \\
\hline $\begin{array}{l}2011 \text { (before } \\
\text { construction) }\end{array}$ & 136,392 & 273,118 & \\
$\begin{array}{l}2015 \text { (under } \\
\text { construction) }\end{array}$ & 144,698 & 306,430 & 127,471 \\
$\begin{array}{l}2019 \text { (after } \\
\text { construction) }\end{array}$ & 152,217 & 375,408 & \\
\hline
\end{tabular}

1 
Table 9 (on next page)

WorldPop, Remote sensing, and HRSL population statistics. 


\begin{tabular}{|c|c|c|c|}
\hline Time & $\begin{array}{c}\text { WorldPop } \\
\text { population statistics }\end{array}$ & $\begin{array}{c}\text { Remote sensing } \\
\text { visual } \\
\text { interpretation }\end{array}$ & $\begin{array}{c}\text { HRSL } \\
\text { population data } \\
\text { statistics } \\
\end{array}$ \\
\hline $\begin{array}{l}2011 \text { (before } \\
\text { construction) }\end{array}$ & 8 & 1790 & \\
\hline $\begin{array}{l}2015 \text { (under } \\
\text { construction) }\end{array}$ & 19 & 2785 & 95 \\
\hline $\begin{array}{l}2017 \text { (under } \\
\text { construction) }\end{array}$ & 16 & 3365 & \\
\hline 2019 (after construction) & 17 & 3870 & \\
\hline
\end{tabular}

1 
Table $\mathbf{1 0}$ (on next page)

Accuracy veri $\square$ cation table. 


\begin{tabular}{|c|c|c|c|c|}
\hline Area & Expressway & Source & RMSE & $\%$ RMSE \\
\hline \multirow{5}{*}{ Large area range } & Cherchell Ring Expressway & \multirow[b]{2}{*}{ WorldPop } & \multirow[b]{2}{*}{26,516} & \multirow[b]{2}{*}{10.01} \\
\hline & North-South Expressway & & & \\
\hline & Bejaia Expressway & \multirow{3}{*}{ HRSL } & \multirow{3}{*}{50,270} & \multirow{3}{*}{18.98} \\
\hline & Tipaza Expressway & & & \\
\hline & East-West Expressway & & & \\
\hline \multirow{3}{*}{ Middle area } & \multirow{3}{*}{ Bejaia Expressway } & WorldPop & 10,516 & 6.78 \\
\hline & & HRSL & 27,743 & 17.87 \\
\hline & & $\begin{array}{c}\text { NDBI building area } \\
\text { estimate }\end{array}$ & 15,216 & 97.42 \\
\hline \multirow[b]{3}{*}{ Small area } & \multirow[b]{3}{*}{ Tikhramtath town } & WorldPop & 751 & 97.53 \\
\hline & & HRSL & 675 & 87.66 \\
\hline & & $\begin{array}{c}\text { Remote sensing } \\
\text { visual interpretation } \\
\text { data }\end{array}$ & 2015 & 261.69 \\
\hline
\end{tabular}

